\title{
TITLE:
}

\section{ON THE DIURNAL VERTICAL MIGRATION OF HYDROMEDUSAE OFF SANTOS, BRAZIL}

$\operatorname{AUTHOR}(\mathrm{S})$ :

Moreira, Gloria Soares

\section{CITATION:}

Moreira, Gloria Soares. ON THE DIURNAL VERTICAL MIGRATION OF HYDROMEDUSAE OFF SANTOS, BRAZIL. PUBLICATIONS OF THE SETO MARINE BIOLOGICAL LABORATORY 1973, 20: $537-566$

ISSUE DATE:

1973-12-19

URL:

http://hdl.handle.net/2433/175759

RIGHT: 


\title{
ON THE DIURNAL VERTICAL MIGRATION OF HYDROMEDUSAE OFF SANTOS, BRAZIL
}

\author{
GLóRIA SOARES MOREIRA ${ }^{11}$ \\ Instituto de Biologia Marinha, Universidade \\ de São Paulo, Brazil
}

With 23 Text-figures

\begin{abstract}
Eleven 24 hour-stations were set from April 1960 through November 1962, in a certain area off the coast of Santos, Southern Brazil. The samples were collected at these stations at several depths every four hours. Sixteen different species of Hydromedusae were found, besides the Obelia spp., Solmaris spp. and Phialidium spp. Merga tergestina was newly recorded for the South Atlantic Ocean. The following species showed a marked diurnal vertical migration: Ectopleura dumortieri, Euphysora gracilis, Turritopsis nutricula, Cytaeis tetrastyla, Obelia spp., Proboscidactyla ornata, Liriope tetraphylla and Cunina octonaria. Bougainvillia frondosa, Laodicea minuscula, Phialidium spp., Amphogona apsteini, Aglaura hemistoma and Solmundelia bitentaculata were found but in an insufficient number to allow detailed analyses or did not show any definitely clear migration during the present observations; though it could be inferred on the data so far accumulated that they probably migrate. The available data are not enough to describe the behaviour of Eucodonium brownie, Merga tergestina, Eucheilota duodecimalis, Bougainvillia ramosa and Solmaris spp.

The thermocline appears to act as a barrier to the migrational movement of Proboscidactyla ornata. The majority of specimens of Ectopleura dumortieri, Turritopsis nutricula and Obelia spp. migrated between the bottom and the mid-water (in the subtropical water mass). Euphysora gracilis, Liriope tetraphylla and Cytaeis tetrastyla did not migrate up to the surface when the low salinity water occupied there. The temperature and salinity ranges were given newly to some more species.
\end{abstract}

\section{Contents}

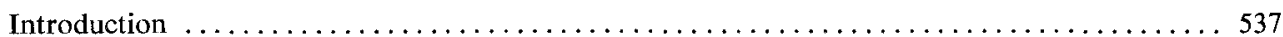

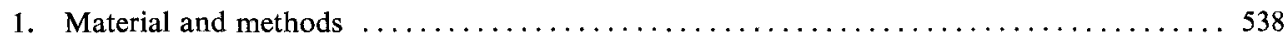

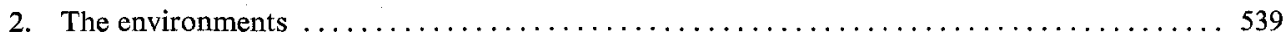

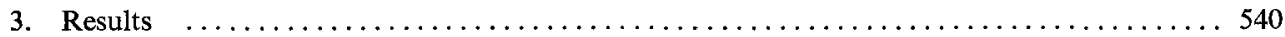

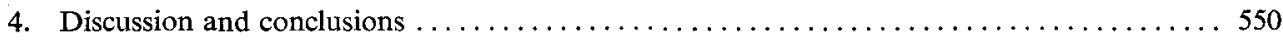

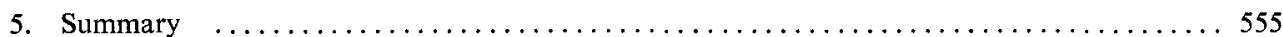

References $\ldots \ldots \ldots \ldots \ldots \ldots \ldots \ldots \ldots \ldots \ldots \ldots \ldots \ldots \ldots \ldots \ldots \ldots \ldots \ldots \ldots \ldots \ldots \ldots \ldots$

\section{Introduction}

The diurnal vertical migration of plankton is well known and BoGorov (1958) has

1) Author's address: Instituto de Biologia Marinha, Universidade de São Paulo, Caixa Postal 11230 , São Paulo S. P. Brazil. 
even estimated that three quarters of the zooplankton migrate diurnally. The presence of a larger number of plankton organisms in surface layers at night has been known since CUVIER (1882) and recently confirmed in different areas by many authors such as Bogorov (1964) in the Arctic in September, KING and Hidn $(1954,1957)$ and HidA and KING (1955) in the Equatorial Pacific, Wiborg (1955) in the Norwegian waters, Legand (1958) in the tropical South Pacific, Hure (1961) in the Adriatic Sea, and MCAlLister (1961) in the Gulf of Alaska.

The most recent review on vertical migration of plankton was given by VINOGRADOV (1968). The vertical migration of medusae was mentioned early by WALTER (1893), Gough (1905), and then by Russell (1925, 1927, 1928 and 1953), MaCKINTOSH (1934), VANnuCCi (1957, 1963), Furnestin (1959), Vucetic (1961) and VerweY (1966), but no regular studies on this problem have yet been undertaken as far as I am aware. Of these authors, only VANNUCCI (op. cit.) referred to specimens of the southern Brazilian waters.

Zooplankton groups off the southern Brazilian coast have been studied chiefly concerning the descriptions of species and their distributions in relation to different water masses in the region, e.g. on chaetognaths (Almeida Prado, 1960, 1961, 1968), copepods (BJoRnBerg, 1963, 1965) and appendicularians (Forneris, 1965). The medusae were fairly well studied by VANNUCCI (op. cit.) who Has done a systematic survey of Hydrozoa collected mainly off the southern Brazilian coast. VANNUCCI and Moreira (1966) and Moreira and Yamashita (1972) made some additional contributions to this. Further, BJöRNBERG and WILBUR (1968) studied in the laboratory the diurnal migratory cycle of some copepods obtained from Ubatuba, State of São Paulo, and the influence of xanthene dyes on their behaviour.

The purpose of this paper is to present some more comprehensive data of some Hydromedusae on their behaviour of diurnal vertical migration to perfect a preliminary note on the vertical migration of medusae previously published by MorEIRA (1965). For some species which were found in an insufficient number to allow any detailed analyses, only some ecological notes are recorded.

\section{Material and Methods}

Eleven 24-hour stations were set from April 1960 through November 1962, 24 miles SSE off Santos Harbour $\left(24^{\circ} 17^{\prime} \mathrm{S}, 46^{\circ} 00^{\prime} \mathrm{W}\right)$, State of São Paulo, southern Brazil; the area is $50 \mathrm{~m}$ deep. The original plan of making observations of four stations each year could not be followed exactly due to bad weather and ship repairs, works at two stations were interrupted on December 29, 1960 and July 5, 1962 due to rough weather, salps and doliolids occurred so densely on November 28, 1960 that it was impossible to obtain plankton samples quantitatively, and on March 30, 1962 the medusae were so rare that the data on that day were regarded as insignificant.

At each station water samples were taken with a Nansen bottle at standard depths 
every four hours and the temperature was read. A bathythermograph was also used at the same time. Plankton samples were taken with a closing standard plankton net rigged with No. 3 gauze ( 64 meshes per inch) and by towing the net for $15 \mathrm{~min}$. at each of three levels, surface, just above the bottom and at mid-water, at a speed of $0.5 \mathrm{kn}$ as far as possible. The hauls at different depths were made successively but not simultaneously, though all the values are interpolated together in respective sections of seven standard time spans within the 24-hour period in figures and on tables.

The amount of filtered water was estimated from the volume of the water column cut through by the net mouth. The salinity was read by titration and the dissolved oxygen was measured by the WINKLER's method. Either total medusae or subsamples taken with a 5cc STEMPLE-pipette and whirling flask were counted. In this paper, only the adults were treated for the data.

Altogether 214 plankton samples were collected and they are stored at the Zoology Department, Institute of Biosciences, São Paulo University.

\section{The Environments}

The hydrography of the oceanic area off southern Brazil is not yet thoroughly studied. In addition to the reports of the "Meteor" Expedition, there are recent studies by Emilsson (1956, 1959, 1961, 1963), Moreira da Silva (1957), OKuda (1962), Moreira da Silva et al. (1966), Mesquita (1969), MASCARENHAS et al. (1971) and others. EMiLsson $(1956,1961)$ reported an upwelling for the first time to the south of Cabo Frio and wrote the most complete paper on the Brazilian coastal waters known to date, mainly on the basis of oceanographic observations in the region between the Abrolhos Banks $\left(18^{\circ} \mathrm{S}\right)$ and the River Plate estuary $\left(35^{\circ} \mathrm{S}\right)$. These results were vastly employed as the basis for the present work.

Thermal Structure: The prevailing conditions in the area may be summarized as follows. During the southern winter, June-August, vertical mixing prevails and the water column is fairly homogeneous with temperatures varying from 20 to $23^{\circ} \mathrm{C}$. Between September and December a thermal stratification is gradually built up until a well marked thermocline is established in the southern summer, from December to February. The thermocline is then gradually broken up between March and May. During summer, the temperature in the upper layer may rise to $25-27^{\circ} \mathrm{C}$, while the temperature below the thermocline is usually maintained around $20^{\circ} \mathrm{C}$ or lower, down to $14^{\circ} \mathrm{C}$. The bottom or near bottom temperatures are thus usually lower in summer than in winter. The inverted thermal cycle in lower layers is due to the upwelling of deep subtropical water over the shelf, that is more pronounced in summer (EMILsson 1961 and 1963).

Water Masses: EMILSSON $(1959,1961)$ has shown that four different water masses are definable in this region: a) Tropical Water, with salinity higher than $36 \%$ and temperature usually higher than $20^{\circ} \mathrm{C}$ and carried southwards by the Brazil Current; 
b) Sub-tropical Water belonging to the Central Water of the South Atlantic, with salinity of $35-36 \%$ and temperature ranging from $10^{\circ} \mathrm{C}$ to $20^{\circ} \mathrm{C}$, and moving northwards and westwards under the Tropical Water. c) Coastal Water, formed near the shore by local heating and by admixture of fresh water from the land and with salinity lower than $35 \%$ and temperature usually higher than $20^{\circ} \mathrm{C}$. d) Shelf Water, formed over the shelf by mixing of Tropical, Sub-tropical and Coastal waters, influenced by local heating, and with salinity from 35 to $36 \%$ and temperature higher than $20^{\circ} \mathrm{C}$.

These water masses were found alternatively in different seasons. In general, it may be stated that due to the uniformity of the water mass in winter, the environment does not suffer any abrupt or extreme changes in temperature or salinity during this season, while in summer these factors fluctuate quite frequently due to the invasion of water masses of different T-S characteristics into the region.

\section{Results}

\section{A. ORDER ANTHOMEDUSAE}

Ectopleura dumortieri (VAN BENEDEN, 1844)

Number of specimens: 1 (IV. 8, 1960): 8 (VII. 6-7, 1961); 1, 115 (XI. 7-8, 1961).

Elological notes: Salinity, 35.35-36.00\% ; temperature, $15.0-22.6^{\circ} \mathrm{C}$; oxygen, $3.67-5.60 \mathrm{ml} / 1$.

Maximum density: 6.44 spec. $/ \mathrm{m}^{8}$ (35.57\%o salinity; $15.12^{\circ} \mathrm{C}$ temperature; $4.37 \mathrm{ml} / \mathrm{l}$ oxygen; $45 \mathrm{~m}$ deep; November 7, 1961; midnight).

Vertical migration. The vertical migration was studied on November 7-8, 1961 (Fig. 1). The densities (specimens $/ \mathrm{m}^{3}$ ) at different depths are indicated in Table 1.

Table 1. Density of Ectopleura dumortieri $\left(\mathrm{spec} / \mathrm{m}^{3}\right)$.

\begin{tabular}{|c|c|c|c|c|c|c|c|c|}
\hline Date & Depth $(\mathrm{m})$ & 08:00 & $12: 00$ & $16: 00$ & $20: 00$ & $24: 00$ & $04: 00$ & 08:00 \\
\hline \multirow{3}{*}{ 7. XI. 1961} & 0 & 0.00 & 0.00 & 0.00 & 0.02 & 0.02 & 0.00 & 0.00 \\
\hline & $20-25$ & 0.35 & 1.64 & 0.13 & 1.33 & 0.33 & 0.00 & 0.02 \\
\hline & 45 & 1.15 & 0.82 & 0.31 & 0.75 & 6.44 & 6.00 & 0.88 \\
\hline
\end{tabular}

The species was almost completely absent at the surface throughout the 24 -hour period. The greatest densities were registered near the bottom, except at noon and 8:00 p.m. This fact suggests the migration up to mid-water at these times. The ascent at noon occurred also in almost all the species present on that day and seemed to be an exceptional behaviour, since in other observations the medusae usually occurred near the bottom at noon. This exception, however, could not be related to any measured physical or chemical parameters. The daily migration of Ectopleura dumortieri up to the mid-water occurred at sunset, but the medusae sank or moved down again before midnight. 
Euphysora gracilis (BRoOKs, 1882)

Numbrt of specimens: 66 (IV, 8. 1960); 33 (IX. 22-23, 1960); 584 (III. 21-22, 1961); 162 (VII. 6-7, $1961) ; 6,477$ (XI. 7-8, 1961); 90 (XI. 28, 1962).

Ecology notes: Salinity, 34.78-36.15\%; temperature, $15.0-26.9^{\circ} \mathrm{C}$; oxygen, $3.67-5.11 \mathrm{ml} / 1$

Maximum density: 25.8 spec. $/ \mathrm{m}^{3}$ (35.55\% salinity; $15.0^{\circ} \mathrm{C}$ temperature; $3.67 \mathrm{ml} / 1$ oxygen; $45 \mathrm{~m}$ deep; November 7, 1961; 8:00 a. m.)

Vertical migration. The vertical migration was studied on March 21-22, 1961 (Fig. 2), July 6-7, 1961 (Fig. 3) and November 7-8, 1961 (Fig. 4). The densities at different depths are given on Table 2 .

Table 2. Density of Euphysora gracilis (spec. $/ \mathrm{m}^{3}$ ).

\begin{tabular}{|c|c|c|c|c|c|c|c|c|}
\hline Date & Depth $(\mathrm{m})$ & $16: 00$ & $20: 00$ & $24: 00$ & $04: 00$ & 08:00 & $12: 00$ & $16: 00$ \\
\hline \multirow{3}{*}{ 21. III. 1961} & 0 & 0.00 & 0.13 & 0.00 & 0.00 & 0.00 & 0.00 & 0.66 \\
\hline & $20-25$ & 0.40 & 1.33 & 1.06 & 0.26 & 0.00 & 0.00 & 0.66 \\
\hline & 45 & 3.33 & 0.55 & 0.00 & 0.33 & 2.11 & 1.88 & 2.11 \\
\hline \multirow{5}{*}{ 6. VII. 1961} & Depth $(\mathrm{m})$ & $12: 00$ & $16: 00$ & $20: 00$ & $24: 00$ & $04: 00$ & $08: 00$ & $12: 00$ \\
\hline & 0 & 0.00 & 0.00 & 0.13 & 0.02 & 0.00 & 0.00 & 0.00 \\
\hline & $20-25$ & 0.04 & 0.00 & 0.28 & 0.40 & 0.17 & 0.02 & 0.00 \\
\hline & 45 & 0.33 & 0.48 & 0.26 & 0.46 & 0.51 & 0.37 & 0.06 \\
\hline & Depth $(\mathrm{m})$ & $08: 00$ & $12: 00$ & $16: 00$ & $20: 00$ & $24: 00$ & 04:00 & 08:00 \\
\hline \multirow{3}{*}{ 7. XI. 1961} & 0 & 0.00 & 0.02 & 0.00 & 8.62 & 1.35 & 0.08 & 0.57 \\
\hline & $20-25$ & 9.68 & 14.82 & 3.91 & 7.11 & 4.77 & 16.66 & 2.22 \\
\hline & 45 & 25.88 & 8.22 & 19.55 & 3.06 & 4.66 & 7.11 & 5.55 \\
\hline
\end{tabular}

On March 21-22, 1961, the data indicate an ascent to the mid-water in the evening and a descent at dawn. As this species prefers the cold water $\left(15-17^{\circ} \mathrm{C}\right)$, higher temperatures at the surface $\left(25^{\circ} \mathrm{C}\right)$ seems to prevent the upward movement to the surface. The thermocline, per se, is not a barrier, since at another station with a thermocline (November 7-8, 1961), the majority of specimens migrated from near the bottom to the surface at night, when the surface temperature was not so high as on March 21-22.

The movement was similar to the above-mentioned one on July 6-7, 1961 (Fig. 3), when neither thermocline nor surface water of higher temperatures was observed there, but the surface layer above $20 \mathrm{~m}$ was covered by the coastal water and probably this less saline water (less than $35 \%$ ) acted as a barrier for the ascending movement, since the species prefers more saline water.

On November 7-8, 1961 (Fig. 4), the majority of specimens migrated from near the bottom to the surface at night (8:00 p.m.). The data suggest an ascent at noon, but this is already discussed above. Neither thermocline nor the surface water with 
temperature around $22^{\circ} \mathrm{C}$ did prevent the upward movement to the surface.

\section{Eucodonium brownie HARTLAUB, 1907}

Number of specimens: 24 (I. 9; 1962).

Ecological notes: Salinity, $35.35 \%$; temperature, $24.2^{\circ} \mathrm{C}$; oxygen, $6.89 \mathrm{ml} / 1$.

Density: $0,55 \mathrm{spec} . / \mathrm{m}^{3}$

\section{Turritopsis nutricula MCCRADY, 1856}

Number of specimens: 112 (IX. 22-23, 1960); 1 (VII. 8, 1961); 320 (XI. 7-8, 1961); 8 (I. 9-10, 1962). Ecological notes: Salinity, 35.35-35.67\% ; temperature, $14.3-22.6^{\circ} \mathrm{C}$; oxygen, $3.67-5.06 \mathrm{ml} / 1$.

Maximum density: $2.44 \mathrm{spec} / \mathrm{m}^{3}\left(35.62 \%\right.$ salinity; $15.4{ }^{\circ} \mathrm{C}$ temperature $; 4.24 \mathrm{ml} / 1$ oxygen; $25 \mathrm{~m}$ deep; November 8, $1961 ;$ 4:00 a.m.).

Vertical migration. The vertical migration was studied on November 7-8, 1961 (Fig. 5). The densities at different depths are given on Table 3. The species was almost

Table 3. Density of Turritopsis nutricula (spec. $\left./ \mathrm{m}^{3}\right)$.

\begin{tabular}{|c|c|c|c|c|c|c|c|c|}
\hline Date & Depth $(\mathrm{m})$ & $08: 00$ & $12: 00$ & $16: 00$ & $20: 00$ & $24: 00$ & $04: 00$ & 08:00 \\
\hline \multirow{3}{*}{ 7. XI. 1961} & 0 & 0.00 & 0.00 & 0.00 & 0.00 & 0.04 & 0.02 & 0.00 \\
\hline & $20-25$ & 0.17 & 0.22 & 0.02 & 0.88 & 1.00 & 2.44 & 0.00 \\
\hline & 45 & 0.62 & 0.06 & 0.04 & 0.22 & 0.00 & 0.88 & 0.22 \\
\hline
\end{tabular}

absent at surface, with a single exception at midnight. At midnight there was no T. nutricula near the bottom. The greater concentrations in the day-time were found near the bottom, except at noon; but this exception was discussed already. The data suggest that the majority of specimens migrated from the bottom to midwater at night inside the subtropical water mass. The thermocline may limit the upward movement, though no data are available on the behaviour when no thermocline is defined.

\section{Bougainvillia ramosa (VAN BENEDEN, 1844)}

Number of specimens: 5 (XI. 7, 1961).

Ecological notes: Salinity, 35.35-35.64\%; temperature, $15.0-15.1^{\circ} \mathrm{C}$; oxygen, $3.57-4.53 \mathrm{ml} / \mathrm{l}$.

\section{Bougainvillia frondosa MAYER, 1900}

Number of specimens: 19 (IV. 8, 1960); 42 (IX. 22-23. 1960); 38 (III. 21-22, 1961); 5 (VII. 6-7, 1961); 20 (XI. 7-8, 1961); 15 (XI-28, 1962).

Ecological notes: Salinity, 35.27-36.18\%; temperature, $15.1-22.5^{\circ} \mathrm{C}$; oxygen, $3.67-4.98 \mathrm{ml} / 1$.

Maximum density: $0.53 \mathrm{spec} . / \mathrm{m}^{3}$ (35.76\%o salinity; $21.2^{\circ} \mathrm{C}$ temperature; $4.70 \mathrm{ml} / 1$ oxygen; $25 \mathrm{~m}$ deep; September 22, 1960; midnight).

\section{Merga tergestina (NEPPI and STIASNY, 1911)}

Number of specimens: 7 (VI. 8, 1960); 29 (XI. 7-8, 1961).

Ecological notes: Salinity, 35.27-35.67\% ; temperature, $15.0-16.5^{\circ} \mathrm{C}$; oxygen, $3.67-4.53 \mathrm{ml} / 1$.

Maximum density: $0.2 \mathrm{spec} . \mathrm{m}^{3}$ (35.55\%o salinity; $15.4{ }^{\circ} \mathrm{C}$ temperature; $4.37 \mathrm{ml} / 1$ oxygen; $45 \mathrm{~m}$ deep; November 8, 1961; 4:00 a.m.). 
Cytaeis tetrastyla EsCHSCHOLTZ, 1829

Number of specimens: 193 (IX. 22-23, 1960); 8 (III. 21-22, 1961); 36 (VII. 6-7, 1961); 30 (XI. 28, 1962).

Ecological notes: Salinity: $34.79-36.13 \%$; temperature: $15.0-22.6^{\circ} \mathrm{C}$; oxygen: $3.67-5.01 \mathrm{ml} / \mathrm{l}$.

Maximum density: $2.57 \mathrm{spec} . / \mathrm{m}^{3}$ (36.08\%o salinity; $20.0^{\circ} \mathrm{C}$ temperature; $3.85 \mathrm{ml} / \mathrm{l}$ oxygen; $45 \mathrm{~m}$ deep; September 22, 1960; 4:00 p.m.).

Vertical migration. The vertical migration was studied on September 22-23, 1960 (Fig. 6). The densities at different depths are indicated on Table 4.

Table 4. Density of Cytaeis tetrastyla $\left(\mathrm{spec} / \mathrm{m}^{3}\right)$.

\begin{tabular}{|c|r|r|r|r|r|r|r|r|}
\hline \multirow{3}{*}{ Date } & Time (h) & $12: 00$ & $16: 00$ & $20: 00$ & $24: 00$ & $04: 00$ & $08: 00$ & $12: 00$ \\
\cline { 2 - 8 } 22. IX. 1960 & 0 & 0.00 & 0.00 & 0.00 & 0.13 & 0.00 & 0.00 & 0.00 \\
& $20-25$ & 0.02 & 0.00 & 0.13 & 0.13 & 0.33 & 0.00 & 0.00 \\
& 45 & 0.51 & 2.57 & 0.04 & 0.00 & 0.00 & 0.13 & 0.26 \\
\hline
\end{tabular}

In the daytime, the species occurred almost exclusively near the bottom. In the evening, some ascending movement was registered, since the greatest number of specimens was caught in midwater. At midnight the population was distributed from midwater to the surface and no specimens were caught near the bottom.

On July 6-7, 1961, no thermocline was defined, but the coastal water was covering the surface layers. On this day, the ascending movemental at night was limited to the midwater, probably checked by the less saline water.

\section{B. ORDER LEPTOMEDUSAE}

\section{Laodicea minuscula VANNUCCI, 1957}

Number of specimens: 57 (IX. 22-23, 1960); 7 (VII. 6-7, 1961); 11 (XI. 7-8, 1961); 15 (XI. 28, 1962). Ecological notes: Salinity, 34.76-36.11\%; temperature, $15.4-23.2^{\circ} \mathrm{C}$, oxygen, $3.69-5.95 \mathrm{ml} / 1$.

Maximum density: 0.4 spec. $/ \mathrm{m}^{3}$ (36.11\%o salinity; $19.8^{\circ} \mathrm{C}$ temperature; $3.85 \mathrm{~m} 1 / 1$ oxygen; $45 \mathrm{~m}$ deep; September 22, 1960; at noon).

\section{Obelia spp.}

Number of specimens: 34 (IX. 22-23, 1960); 11 (VII. 6-7, 1961); 438 (XI. 7-8, 1961).

Ecological notes: Salinity, 35.32-36.13\%o; temperature, $15.0-22.5^{\circ} \mathrm{C}$; oxygen, $3.67-5.06 \mathrm{ml} / 1$.

Maximum density: $3.6 \mathrm{spec} . / \mathrm{m}^{3}\left(35.35 \%\right.$ salinity; $15.0^{\circ} \mathrm{C}$ temperature; $3.67 \mathrm{ml} / 1$ oxygen; $45 \mathrm{~m}$ deep; November 7, 1961; 8:00 a.m.).

Vertical migration. The vertical migration was studied on November 7-8, 1961 (Fig. 7). The densities at different depths are shown on Table 5.

Table 5. Density of Obelia spp. (spec. $/ \mathrm{m}^{3}$ ).

\begin{tabular}{|c|c|c|c|c|c|c|c|c|}
\hline \multirow{2}{*}{ Date } & Time (h) & $08: 00$ & $12: 00$ & $16: 00$ & $20: 00$ & $24: 00$ & $04: 00$ & $08: 00$ \\
\hline \multirow{3}{*}{ 7. XI. 1961 } & 0 & 0.00 & 0.00 & 0.00 & 0.06 & 0.24 & 0.00 & 0.00 \\
& $20-25$ & 0.26 & 0.20 & 0.08 & 0.66 & 0.55 & 0.88 & 0.00 \\
& 45 & 3.60 & 0.55 & 0.08 & 0.04 & 0.00 & 1.33 & 1.11 \\
\hline
\end{tabular}


At 8:00 a.m. and noon, great concentrations were registered in deep water, some specimens were found in the midwater, but none at the surface. At 4:00 p.m., similar densities occurred near the bottom and in the midwater. This seems to suggest an ascending movement. At 8:00 p.m., 85.7\% of the specimens were caught in the midwater, $8.6 \%$ at surface and only $5.7 \%$ near the bottom. At midnight, the density at surface increased, though the greatest density was maintained in the midwater, no specimen was caught near the bottom. At 4:00 a.m., 60\% were caught near the bottom, $40 \%$ in the midwater, but none at surface. These facts suggest a descending movement after midnight. At 8:00 the next morning, 24 hours after the first haul, all specimens came from the deep water. The ascending movement at night was generally limited to the midwater, possibly due to the presence of thermocline between 7 and $15 \mathrm{~m}$.

\section{Phialidium spp.}

Number of specimens: 5 (IV. 8, 1960); 28 (IX. 22-23, 1960); 110 (VII. 6-7, 1961); 33 (XI, 7-8. 1961); 16 (I. 9-10. 1962); 90 (XI. 28, 1962).

Ecological notes: Salinity, 34.78-36.13\%; temperature, $15.0-25.1^{\circ} \mathrm{C}$; oxygen, $3.67-6.58 \mathrm{ml} / 1$.

Maximum density: $\quad 0.66 \mathrm{spec} . / \mathrm{m}^{3}$ ( $34.88 \%$ salinity; $25.0^{\circ} \mathrm{C}$ temperature; $4.80 \mathrm{ml} / 1$ oxygen; , surface; November 28, 1962; at midnight).

Eucheilota duodecimalis (A. AgassIz, 1882)

Number of specimens: 1 (VII, 6. 1961); 2(XI, 7. 1961).

Ecological notes: Salinity, 34.78-35.6\%; temperature, $21.6-22.8^{\circ} \mathrm{C}$; oxygen; $5.0-5.10 \mathrm{ml} / \mathrm{l}$.

\section{ORDER LIMNOMEDUSAE}

Proboscidactyla ornata (MCCRADY, 1857)

Number of specimens: 10 (IV. 8, 1960); 484 (IX. 22-23, 1960); 2,489 (III. 21-22, 1961); 29 (.VII. 6-7, 1961); 130 (XI. 7-8, 1961); 786 (I. 9-10, 1962); 60 (XI. 28, 1962).

Ecological notes: Salinity, 34.78-36.17\% ; temperature, $14.1-26.9^{\circ} \mathrm{C}$; oxygen, $3.67-5.60 \mathrm{ml} / \mathrm{l}$.

Maximum density: $26.3 \mathrm{spec} . / \mathrm{m}^{3}\left(35.77 \%\right.$ salinity; $16.8^{\circ} \mathrm{C}$ temperature; $4.37 \mathrm{ml} / 1$ oxygen; $45 \mathrm{~m}$ deep; March 30, 1961; 4:00 p.m.).

Vertical migration. The vertical migration was studied on September 22-23, 1960 (Fig. 8), March 21-22, 1961 (Fig. 9), November 7-8, 1961 (Fig. 10) and January 9-10, 1962 (Fig. 11). The densities at different depths are presented on Table 6.

On September 22-23, 1960, an impressive example of the daily vertical migration was observed, when almost $100 \%$ of the specimens were caught near the bottom in the day time, in the midwater at 8:00 p.m. and 4:00 a.m., but the majority at the surface at midnight. No thermocline was registered on that day.

On March 21-22, 1961 and January 9-10, 1962, the night movement from deep water to midwater was registered. A thermocline was defined on those days and probably it acted as a barrier for the ascending movement.

On November 7-8, 1961, when a thermocline was defined as well as at other 24-hour stations, the species was almost absent in any of the surface samples. The greatest densities were registered in the midwater at night and near the bottom in the 
Table 6. Density of Proboscidactyla ornata $\left(\mathrm{spec} / \mathrm{m}^{3}\right)$.

\begin{tabular}{|c|c|c|c|c|c|c|c|c|}
\hline Date & $\begin{array}{l}\text { Time (h) } \\
\text { Depth }(\mathrm{m})\end{array}$ & $12: 00$ & $16: 00$ & $20: 00$ & $24: 00$ & 04:00 & 08:00 & $12: 00$ \\
\hline \multirow{4}{*}{ 22. IX.. 1960} & 0 & 0.00 & 0.00 & 0.00 & 2.06 & 0.00 & 0.00 & 0.00 \\
\hline & $20-25$ & 0.02 & 0.00 & 0.51 & 0.93 & 0.86 & 0.00 & 0.00 \\
\hline & 45 & 0.75 & 1.71 & 0.08 & 0.13 & 1.13 & 1.73 & 1.80 \\
\hline & Depth (m) & $16: 00$ & $20: 00$ & 24:00 & 04:00 & 08:00 & $12: 00$ & $16: 00$ \\
\hline \multirow{3}{*}{ 21. III. 1961} & 0 & 0.00 & 0.13 & 0.26 & 0.00 & 0.00 & 0.00 & 0.00 \\
\hline & $20-25$ & 0.73 & 8.22 & 6.80 & 0.53 & 0.26 & 0.55 & 0.11 \\
\hline & 45 & 26.33 & 2.44 & 0.46 & 2.77 & 2.77 & 1.66 & 1.22 \\
\hline \multirow{5}{*}{ 7. XI. 1961} & Depth (m) & 08:00 & $12: 00$ & $16: 00$ & $20: 00$ & $24: 00$ & 04:00 & 08:00 \\
\hline & 0 & 0.00 & 0.00 & 0.00 & 0.00 & 0.00 & 0.00 & 0.00 \\
\hline & $20-25$ & 0.20 & 0.44 & 0.02 & 0.44 & 0.55 & 0.00 & 0.04 \\
\hline & 45 & 0.57 & 0.06 & 0.04 & 0.08 & 0.00 & 0.22 & 0.17 \\
\hline & $\begin{array}{l}\text { Time (h) } \\
\text { Depth }(\mathrm{m})\end{array}$ & 16:00 & $20: 00$ & $24: 00$ & 04:00 & 08:00 & $12: 00$ & $16: 00$ \\
\hline \multirow{3}{*}{ 9. I. 1962} & 0 & 0.00 & 0.00 & 0.00 & 0.00 & 0.00 & 0.00 & 0.00 \\
\hline & $20-25$ & 0.00 & 2.31 & 2.84 & 1.33 & 0.00 & 0.00 & 0.00 \\
\hline & 45 & 0.71 & 1.33 & 0.00 & 0.88 & 2.66 & 1.11 & 4.44 \\
\hline
\end{tabular}

daytime, except at noon-this exception was common to the majority of the species occurred on that day.

\section{ORDER TRACHYMEDUSAE}

\section{Liriope tetraphylla (CHAMISSO and EYSENHARDT, 1821)}

Number of specimens: 2,353 (IV. 8, 1960); 916 (IX. 22-23, 1960); 5,601 (III. 21-22, 1961); 1,978 (VII. 6-7, 1961); 1,928 (XI. 7-8, 1961); 101,866 (I. 9-10, 1962); 3,575 (XI. $28,1962)$.

Ecological notes: Salinity, 34.63-36.18\%; temperature, $14.1-27.0^{\circ} \mathrm{C}$; oxygen, $3.67-6.89 \mathrm{ml} / 1$.

Maximum density: 260 spec. $/ \mathrm{m}^{3}\left(35.38 \%\right.$ salinity; $15.2^{\circ} \mathrm{C}$ temperature; $6.51 \mathrm{ml} / 1$ oxygen; $25 \mathrm{~m}$ January 10, 1962; of noon).

Vertical migration. The vertical migration was studied on April 8, 1960 (Fig. 12), September 22-23, 1960 (Fig. 13), March 21-22, 1961 (Fig. 14), July 6-7, 1961 (Fig. 15), November 7-8, 1961 (Fig. 16), January 9-10, 1962 (Fig. 17) and on November 28, 1962 (Fig. 18). The densities are indicated on Table 7.

On April 8, 1960, at midnight, the majority of the specimens were found at the surface $(74.7 \%$ ). At 4:00 a.m., the maximum density was found in the midwater, and this suggested the beginning of a descending movement. At 8:00 a.m., the density near the bottom was greater than at midnight, though the greatest density was registered in the midwater and the species was almost absent in the surface sample. Atnoon, $90 \%$ 
Table 7. Density of Liriope tetraphylla (spec. $\left./ \mathrm{m}^{3}\right)$.

\begin{tabular}{|c|c|c|c|c|c|c|c|c|}
\hline Date & $\begin{array}{l}\text { Time (h) } \\
\text { Depth (m) }\end{array}$ & $00: 00$ & 04:00 & 08:00 & $12: 00$ & $16: 00$ & $20: 00$ & $24: 00$ \\
\hline \multirow{4}{*}{ 8. IV. 1960} & 0 & 6.37 & 4.00 & 0.08 & 0.00 & 0.22 & 0.66 & 1.62 \\
\hline & $20-25$ & 1.44 & 6.66 & 3.75 & 1.15 & 3.02 & 3.97 & 1.33 \\
\hline & 45 & 0.71 & 0.97 & 3.46 & 10.40 & 0.97 & 0.44 & 0.82 \\
\hline & $\mid \begin{array}{c}\text { Time (h) } \\
\text { Depth }(\mathrm{m})\end{array}$ & $12: 00$ & $16: 00$ & $20: 00$ & $24: 00$ & 04:00 & 08:00 & $12: 00$ \\
\hline \multirow{4}{*}{ 22. IX. 1960} & 0 & 0.06 & 0.55 & 0.17 & 2.46 & 0.20 & 0.13 & 0.40 \\
\hline & $20-25$ & 0.13 & 0.80 & 2.06 & 1.33 & 1.66 & 0.60 & 0.20 \\
\hline & 45 & 1.86 & 3.06 & 0.75 & 0.73 & 0.13 & 1.46 & 1.53 \\
\hline & $\begin{array}{c}\text { Time (h) } \\
\text { Depth }(\mathrm{m})\end{array}$ & $16: 00$ & 20:00 & $24: 00$ & 04:00 & 08:00 & $12: 00$ & $16: 00$ \\
\hline \multirow{4}{*}{ 21. III. 1961} & 0 & 2.11 & 12.26 & 14.80 & 5.73 & 0.26 & 2.02 & 6.44 \\
\hline & $20-25$ & 4.66 & 10.44 & 10.26 & 13.20 & 6.53 & 5.57 & 7.22 \\
\hline & 45 & 8.22 & 0.55 & 1.04 & 2.88 & 3.33 & 2.53 & 4.33 \\
\hline & Depth (m) & $12: 00$ & $16: 00$ & 20:00 & $24: 00$ & 04:00 & $08: 00$ & $12: 00$ \\
\hline \multirow{4}{*}{ 6. VII. 1961} & 0 & 0.24 & 0.48 & 2.15 & 1.20 & 0.37 & 0.06 & 0.02 \\
\hline & $20-25$ & 1.44 & 2.35 & 5.33 & 5.11 & 6.35 & 4.35 & 1.00 \\
\hline & 45 & 8.37 & 0.82 & 0.26 & 0.20 & 0.60 & 1.60 & 1.57 \\
\hline & Depth $(\mathrm{m})$ & 08:00 & $12: 00$ & $16: 00$ & 20:00 & $24: 00$ & 04:00 & 08:00 \\
\hline \multirow{3}{*}{ 7. XI. 1961} & 0 & 0.22 & 0.00 & 0.04 & 4.80 & 1.40 & 0.28 & 0.31 \\
\hline & $20-25$ & 3.35 & 1.66 & 0.75 & 3.55 & 2.55 & 7.33 & 0.44 \\
\hline & 45 & 5.53 & 1.08 & 1.51 & 0.64 & 1.55 & 3.77 & 2.00 \\
\hline \multirow{5}{*}{ 9. I. 1962} & Depth $(\mathrm{m})$ & $16: 00$ & $20: 00$ & $24: 00$ & 04:00 & 08:00 & $12: 00$ & $16: 00$ \\
\hline & 0 & 45.33 & 91.20 & 175.46 & 65.24 & 75.33 & 4.00 & 54.66 \\
\hline & $20-25$ & 62.22 & 250.13 & 92.22 & 195.73 & 84.00 & 62.22 & 101.33 \\
\hline & 45 & 130.66 & 78.66 & 43.77 & 65.24 & 137.33 & 260.00 & 144.44 \\
\hline & Depth (m) & 00:00 & $04: 00$ & $08: 00$ & $12: 00$ & $16: 00$ & 20:00 & $24: 00$ \\
\hline \multirow{3}{*}{ 28. XI. 1962} & 0 & 0.66 & 0.77 & 0.33 & 0.33 & 2.33 & 2,33 & 2.00 \\
\hline & $20-25$ & 4.66 & 7.33 & 0.66 & 2.00 & 4.66 & 3,00 & 11.33 \\
\hline & 45 & 3.33 & 6.00 & 6.66 & 4.00 & 10.33 & 8,66 & 2.66 \\
\hline
\end{tabular}

of the specimens was caught near the bottom and 10\% in the midwater. At 4:00 and 8:00 p.m. the greatest densities were found in the midwater, the density near the bottom decreased and only some specimens caught at the surface. At the next mid- 
night, the distribution of species densities at different depths returned to a pattern similar to that observed 24 hours before.

On September 22-23, 1960, at noon and at 4:00 p.m., most of the specimens were found in deep layer samples. At 8:00 p.m., the percentage of animals decreased near the bottom and increased in the midwater, indicating an ascending movement after 4:00 p.m. Most of the specimens were caught at surface at midnight, but in the midwater at 4:00 a.m. Thus, there was an evident migration of the majority of the animals from near the bottom to the surface at night. At 8 and 12:00 a.m., most of the animals were caught near the bottom again.

On March 21-22, 1961, at 4:00 p.m. the greatest density was registered near the bottom, but at 8:00 p.m. the inverse was observed $(52.7 \%$ at surface, $44.9 \%$ in the midwater and only $2.3 \%$ near the bottom). At midnight the percentage of animals at the surface increased to $56.7 \%$. At 4:00 a.m. the greatest density was found in the midwater and only a few specimens were caught near the bottom and at surface. At 8:00 a.m. the greatest density remained still in the midwater and the species was almost absent at surface. At noon, the greatest density was still found in the midwater as well as at 4:00 p.m. The fact that the majority of specimens did not come down to near the bottom at noon may be due to lower illumination on that day, although the water was very clear (transparency: $26-28 \mathrm{~m}$ ).

On July 6-7, 1961, at noon most of the specimens were caught near the bottom $(83.2 \%)$, some in the midwater and only a few at the surface. At 4:00 p.m., the greatest density was registered in the midwater, and this state became pronounced in following hours. There was a decrease of animals near the bottom and an increase at the surface at 8:00 p.m. The inverse was observed at midnight, 4:00 and 8:00 a.m. At the next noon the greatest density was found again near the bottom, when only a few specimens were present at the surface. On that day, there was a migration from the bottom to the midwater, but not to the surface, this must be due to the less saline coastal water covering the surface layers.

On November 7-8, 1961, at 8:00 a.m. the greatest percentage $(60.6 \%)$ was registered near the bottom and only $36.8 \%$ were caught in the midwater and $2.4 \%$ at the surface. At noon, the greatest density was found in the midwater, but this fact was discussed already for other species collected on that day. At 4:00 p.m. the greatest density was found near the bottom again. At 8:00 p.m. most of the animals were caught near the surface, only $7.2 \%$ near the bottom and $39.5 \%$ in the midwater. At midnight, the greatest density was found in the midwater, suggesting that a descending movement had begun after 8:00 p.m. and continued till 4:00 a.m. At 8:00 a.m. next morning the disbution pattern observed 24 hours before was nearly restored, with the greatest density near the bottom.

On January 9-10, 1962, at 4:00 p.m. the greatest density was registered near the bottom, but at 8:00 p.m. the animals were already in the midwater on their way of ascending movement. At midnight, most of the specimens $(56.3 \%)$ were caught near 
the surface, $29.6 \%$ in the midwater and only $14.1 \%$ near the bottom. After this time, the animals began to descend, with the greatest density in the midwater at 4:00 a.m. and near the bottom at 8:00 a.m. At noon, $72.7 \%$ of the specimens was found near the bottom, $26.7 \%$ in the midwater and only $1.2 \%$ at the surface. At 4:00 p.m., the greatest density was still found near the bottom, but the densities in the midwater and at the surface were greater than at noon. This fact indicates an ascending movement of some specimens after noon.

On November 28, 1962, at midnight the highest munber of the animals $(53.8 \%)$ was observed in the midwater, $38.5 \%$ near the bottom and only $7.7 \%$ at the surface. The same was true at 4:00 a.m., but there was some increase in the density near the bottom. This indicates the descending movement of some animals. At 8:00 a.m. the greatest density $(86.9 \%$ ) was found near the bottom and only $8.7 \%$ of the animals were caught in the midwater and 4.3\% at the surface. At noon, 4:00 and 8:00 p.m., the pattern was approximately the same as at 8:00 a.m. At midnight the greatest density was found in the midwater as 24 hours before. The fact that the ascending movement began after 8:00 p.m. on that day differs from the pattern on other days when the animals were usually already in the midwater or at the surface at this time. On Nov. 28, it was very fine without any clouds and the sunset was very late (after 8:00 p.m.), moreover the water was very clear (transparency: $30 \mathrm{~m}$ ). Probably these were the reasons for the late ascending movement begun after 8:00 p.m. The vertical migration of L. tetraphylla on November 28, 1962, was limited from the bottom to the midwater, but not to the surface, probably checked by the coastal water covering the surface layers.

$$
\text { Amphogona apsteini (VANHOFFEN, 1902) }
$$

Number of specimens: 18 (IX. 22-23, 1960); 30 (VII. 6-7, 1961).

Ecological notes: Salinity, 34.48-36.17\%; temperature, 19.8-22.6; oxygen, 3.85-5.10 ml/1.

Aglaura hemistoma (Peron and Lesueur, 1809)

Number of specimens: 96 (IV. 8, 1960); 666 (IX. 22-23, 1960); 28 (III. 21-22, 1961); 44 (VII. 6-7, 1961); 8 (I. 9, 1962).

Ecological notes: Salinity, 34.76-35.13\%; temperature, $14.6-26.9^{\circ} \mathrm{C}$; oxygen, $3.69-5.10 \mathrm{ml} / 1$.

Maximum density: $2.46 \mathrm{spec} . / \mathrm{m}^{3}\left(36.00 \%\right.$ salinity; $21.2^{\circ} \mathrm{C}$ temperature; $4.60 \mathrm{ml} / 1$ oxygen; $25 \mathrm{~m}$ September 22, 1960; at midnight).

Vertical migration. The vertical migration was studied on September 22-23, 1960 (Fig. 19). The densities at different depths are presented on Table 8.

Table 8. Density of Aglaura hemistoma (spec. $/ \mathrm{m}^{3}$ ).

\begin{tabular}{|c|c|c|c|c|c|c|c|c|}
\hline Date & Time (h) & $12: 00$ & $16: 00$ & $20: 00$ & $24: 00$ & $04: 00$ & $08: 00$ & $12: 00$ \\
\cline { 2 - 8 } 22. IX. 1960 & 0 & 0.26 & 0.66 & 0.00 & 0.93 & 0.40 & 0.53 & 0.40 \\
& $20-25$ & 2.00 & 1.66 & 0.42 & 2.46 & 0.53 & 1.53 & 1.13 \\
& 45 & 0.31 & 0.26 & 0.40 & 0.00 & 0.13 & 040 & 0.33 \\
\hline
\end{tabular}


On September 22-23, 1960, the greatest densities (percentages greater than $50 \%$ ) were always found in the midwater. Any remarkable vertical movement was not noticed. The species was absent near the bottom only at midnight and the percentage of animals at surface was generally slightly greater at night than in the day time, with a single exception. These facts may suggest some vertical movement of some specimens, though the majority remained always in the midwater.

E. ORDER NARCOMEDUSAE

Solmundella bitentaculata (QuOY and GaImARD, 1833)

Number of specimens: 9 (IV. 8, 1960); 1 (XI. 7, 1961); 212 (I. 9-10, 1962).

Ecological notes: Salinity, $35.35-35.56 \%$; temperature, $14.3-16.6^{\circ} \mathrm{C}$; oxygen, $3.67-5.60 \mathrm{ml} / 1$.

Maximum density: $4 \mathrm{spec} . / \mathrm{m}^{3}$ (35.38\%o salinity; $15.21^{\circ} \mathrm{C}$ temperature; $25 \mathrm{~m}$ deep; January 10 , 1962 ; at noon).

Solmaris spp.

Number of specimens: 2 (IX. 22-23, 1960); 11 (III. 21-22, 1961); 93 (VII. 6-7, 1961); 14 (XI. 7-8, $1961) ; 60(\mathrm{XI}, 28,1962)$.

Ecological notes: Salinity, 34.76-36.15\% ; temperature, $16.3-22.3^{\circ} \mathrm{C}$; oxygen; $3.85-5.10 \mathrm{ml} / 1$.

Maximum density: $1.3 \mathrm{spec} . \mathrm{m}^{3}\left(36.15 \%\right.$ salinity; $16.4^{\circ} \mathrm{C}$ temperature; $45 \mathrm{~m}$ deep; November 29,1962 ; at 4:00 pm..).

Table 9. Density of Cunina octonaria $\left(\mathrm{spec} . / \mathrm{m}^{3}\right)$.

\begin{tabular}{|c|c|c|c|c|c|c|c|c|}
\hline \multirow[t]{2}{*}{ Date } & Depth $(\mathrm{m})$ & $00: 00$ & $04: 00$ & 08:00 & $12: 00$ & $16: 00$ & $20: 00$ & $00: 00$ \\
\hline & 0 & 1.62 & 1.53 & 0.00 & 0.00 & 1.37 & 2.55 & 3.35 \\
\hline \multirow[t]{4}{*}{ 8. IV. 1960} & $20-25$ & 3.22 & 10.24 & 0.68 & 0.75 & 1.82 & 2.77 & 2.84 \\
\hline & 45 & 0.13 & 0.51 & 6.51 & 16.73 & 128 & 0.57 & 1.00 \\
\hline & $\begin{array}{r}\text { Time (h) } \\
\text { Depth }(\mathrm{m}) \\
\end{array}$ & $12: 00$ & $16: 00$ & $20: 00$ & $24: 00$ & $04: 00$ & 08:00 & $12: 00$ \\
\hline & 0 & 0.00 & 0.02 & 0.04 & 1.04 & 0.00 & 0.00 & 0.00 \\
\hline \multirow[t]{4}{*}{ 22. IX. 1960} & $20-25$ & 0.00 & 0.00 & 0.53 & 0.73 & 1.06 & 0.66 & 0.00 \\
\hline & 45 & 1.66 & 3.44 & 0.06 & 0.00 & 0.26 & 0.13 & 1.86 \\
\hline & $\begin{array}{c}\text { Time (h) } \\
\text { Depth }(\mathrm{m}) \\
\end{array}$ & $16: 00$ & $20: 00$ & $24: 00$ & $04: 00$ & $08: 00$ & $12: 00$ & $16: 00$ \\
\hline & 0 & 0.44 & 0.13 & 0.66 & 0.00 & 0.00 & 0.00 & 0.00 \\
\hline \multirow[t]{4}{*}{ 21. III. 1961} & $20-25$ & 0.60 & 1.55 & 0.26 & 0.66 & 0.66 & 0.66 & 1.44 \\
\hline & 45 & 2.88 & 0.77 & 0.06 & 0.00 & 1.11 & 1.55 & 1.00 \\
\hline & Depth $(\mathrm{m})$ & $16: 00$ & $20: 00$ & $24: 00$ & $04: 00$ & $08: 00$ & $12: 00$ & $16: 00$ \\
\hline & 0 & 0.00 & 25.42 & 12.97 & 0.00 & 0.00 & 0.00 & 0.00 \\
\hline \multirow[t]{2}{*}{ 9. I. 1962} & $20-25$ & 18.13 & 2.13 & 11.91 & 17.77 & 1.33 & 7.77 & 2.66 \\
\hline & 45 & 2.84 & 2.55 & 0.88 & 26.66 & 9.33 & 22.66 & 3.33 \\
\hline
\end{tabular}


Cunina octonaria MCCRADY, 1857

Number of specimens: 2,680 (IV. 8, 1960); 520 (IX. 22-23, 1960); 654 (III. 21-22, 1961); 3 (VII. 6-7, 1961); 49 (XI. 7-8, 1961); 6,624 (I. 9-10, 1962); 45 (XI. 28, 1962).

Ecological notes: Salinity, 34.88-38.13\%; temperature, $14.2-27.9^{\circ} \mathrm{C}$; oxygen, 3.67-6.80 ml/1.

Maximum density: $25.4 \mathrm{spec} . / \mathrm{m}^{3}\left(35.30 \%\right.$ salinity; $24.2^{\circ} \mathrm{C}$ temperature; $6.80 \mathrm{ml} / 1$ oxygen; surface; January 9,1962 ; at 8:00 p.m.).

Vertical migration. The vertical migration was studied on April 8, 1960 (Fig. 20), September 22-23, 1960 (Fig. 21), March 21-22, 1961 (Fig. 22) and January 9-10, 1962 (Fig. 23). The densities are indicated on Table 9.

Obvious vertical migration was observed at all stations where this species occurred. In the daytime the majority of specimens was found near the bottom, while the inverse was noted at night. At dawn and sunset the majority of specimens was caught in the midwater. The descending movement began seemingly after midnight, because the greatest number of specimens were already in the midwater at 4:00 a.m. The ascending movement showed some variation: on April 8, 1960 and January 9, 1962, the greatest number of specimens were caught in the midwater already at 4:00 p.m., while on September 22, 1960 and March 21, 1961, the majority was still found near the bottom at the same time.

\section{Discussion and Conclusion}

A total of 129,652 medusae was treated, including 8 species of Anthomedusae, 2 species of Leptomedusae, 1 species of Limnomedusae, 3 species of Trachymedusae and 2 species of Narcomedusae, besides Obelia spp., Phialidium spp. (Leptomedusae) and Solmaris spp. (Narcomedusae). These species belong to 14 different families. The occurrence of a greater number of meroplanktonic species is quite natural, since the studied area is a shallow part of the neritic region, where the hydroids may occur.

The present data allow the following conclusions:

1. Five species migrated from the bottom to the surface during the dark hours: $E u$ physora gracilis, Cytaeis tetrastyla, Proboscidactyla ornata, Liriope tetraphylla and Cunina octonaira.

2. The following species migrated from the bottom to the midwater when the thermocline was present: Ectopleura dumortieri, Turritopsis nutricula, Obelia spp. and Proboscidactyla ornata. When thermocline was absent, Proboscidactyla ornata migrated from the bottom to the surface, thus the thermocline appears to act as a barrier to the migratory movement of Proboscidactyla ornata. As to the other species, no data are available for their occurrences at the stations without thermocline, they might have migrated only to the midwater due to their preference for the sutropical water mass.

3. The following species migrated from the bottom to the midwater when the coastal water was covering the surface layers: Euphysora gracilis, Cytaeis tetrastyla and 
Liriope tetraphylla. These species migrated to the surface only when the coastal water was not present there. It is clearly suggested that the water of lower salinities prevented the upwards movement of these species.

The following species, Bougainvillia frondosa, Laodicea minuscula, Phialidium spp., Amphogona apsteini, Aglaura hemistoma and Solmundella bitentaculata, were found either in insufficient number to allow any detailed analyses or did not show any clear migration; but from the known data it may safely be inferred that they probably migrate. Aglaura hemistoma was caught in greater numbers associated with the tropical water, but there is some indication of migration at least of some part of the population.

The present data are not sufficient to describe the behaviour of Eucodonium brownie, Bougainvillia ramosa, Merga tergestina, Eucheilota duodecimalis and Solmaris spp.; as to their vertical migration no data are available so far.

VERWEY (1966) studied the vertical migration of the Scyphomedusae Rhizostomata pulmo and Chrysaora hysoscella in the coastal water of Den Helder (Netherland) and suggested that the change in the current strength or a factor accompanying it (turbulence) as well as changes in light intensity may be considered strong releasers of vertical movements. WELSH et al. (1937) pointed out that the possible differences in the behaviour of animals with and without photosensitive organs should be investigated. In the present material of the medusae presenting vertical migration, only Turritopsis nutricula has ocelli, but no difference has been noticed in the behaviour of this medusa.

The salinity and temperature ranges of the water mass in which the medusae are caught are usually very important for ecological and physiological purposes, but actually little has been presented in published papers. KRAMP (1930) recorded Ectopleura dumortieri from the North Sea at salinities ranging from 34.78 to $35.01 \%$ and from Skagerak (1933) at temperatures around $18^{\circ} \mathrm{C}$. KUHL (1962) found this species at the "Alte Liebe"-Cuxhaven, in July 1952, at salinity of about $20 \%$ and temperature $18^{\circ} \mathrm{C}$. According to VANNUCCI (1963), Ectopleura dumortieri is eurythermal, but prefers the water of temperatures lower than $20^{\circ} \mathrm{C}$. In the present collection all the specimens of this species but 9 were caught in the cold water below the thermocline and this suggests that the species is unable to stand sharp temperature rise. This agrees with earlier findings showing that there is a greater concentration of medusae in the lower layers around noon and 1:00 p.m., when the sun is shining, irrespective of the type of water in the bottom layers (VANNUCCI, op. cit.).

The known limits for Euphysora gracilis were: 33 to $36 \%$ salinity and $16-26^{\circ} \mathrm{C}$ temperature (VANNUCCI, 1963). In the present studies Ectopleura dumortieri, as well as Euphysora gracilis, was caught at temperatures down to $15^{\circ} \mathrm{C}$. The vertical migration of Euphysora gracilis has never been recorded before, but Steenstrupia nutans, a closely allied medusa, has been known to migrate at night from $20 \mathrm{~m}$ to $8 \mathrm{~m}$ or occasionally even to the surface (RUSSELL, 1953). VANNUCCI (1963), studying the samples taken in the daytime, noticed that greater densities of Euphysora gracilis were in the 
lower layers.

Turritopsis nutricula was recorded by VANNUCCI (1957) at temperatures 19 to $21^{\circ} \mathrm{C}$ and salinity 35.5 to $36.25 \%$ and regarded as a good indicator of the shelf water mass along the Brazilian coast. It has been shown to be useful as an indicator of the drift of the Channel water into the southern North Sea, with salinities from 34.61 to $35.23 \%$ (KRAMP, 1930; RUSSELL, 1938). In the present collection, this species was caught in water with salinities also around $35 \%$, but of temperatures down to $14.3{ }^{\circ} \mathrm{C}$. VANNUCCI's suggestion (1957) that Turritopsis nutricula performs diurnal vertical migration is fully confirmed in this paper.

The known range of temperature for Bougainvillia ramosa was 19.2 to $27.7^{\circ} \mathrm{C}$ (VANnuCCI 1963), but the present data extended the lower limit to $15^{\circ} \mathrm{C}$. Vannucci (op. cit.) suggests that this species presumably does not migrate vertically, because specimens were taken at all depths at any time. In the present investigation specimens were too scarce to study their vertical movements.

Bougainvillia frondosa was caught at temperatures from 15.1 to $22.5^{\circ} \mathrm{C}$ and salinities from 35.27 to $36.18 \%$. Previous records of a few specimens off Sta. Catarina State (Brazil) were made at temperature $19.6-20^{\circ} \mathrm{C}$ and salinity 35.44 to $35.57 \%$ (VANNUCCI, 1957). Specimens in the present collection was not numerous enough to make the study of vertical migration possible. They were never taken at the surface. The highest number of specimens was met with near the bottom in the daytime and at $25 \mathrm{~m}$ deep at night. This suggests a slight upward movement during the dark hours, but only up to the midwater even when no thermocline was defined. VucETIC (1961) noticed that another species of the same genus, Bougainvillia autumnalis, occurred in the $1-10 \mathrm{~m}$ and $10-20 \mathrm{~m}$ layers in the daytime, while in the $20-30 \mathrm{~m}$ at night in the Bay Veliko Jezero of the Island of Mljet.

Merga tergestina, described from Trieste by NEPPI and STIASNy (1911), is now for the first time in this region. The medusae have been recorded off the Dalmatian coast by NEPPI (1912) and the hydroid at Naples (VANNUCCI and YAMADA, 1959) and at Ville-franche by A. BRINCKMANN (VANNUCCI and YAMADA, op. cit.), but there are no data about its vertical migration. This is apparently a stenothermal species.

The scarcity of Cytaeis tetrastyla in the present collection is noteworthy, because it has been reported to be abundant in the shelf water mass off Cananeia and further south along the coast of Brazil (VANNUCCI, 1957, 1963). In the present collection, 184 out of 267 specimens $(68 \%)$ were provided with medusa buds, while only two specimens of a total of 2,691 bore medusa buds in the material collected off Cananeia. This shows that vegetative reproduction probably is not an important factor as supposed to produce the patches of this medusa in a short time interval. Medusa buds may be produced in the water of high salinity $(37.38 \%)$ and low temperature $\left(15\right.$ to $\left.16.85^{\circ} \mathrm{C}\right)$ as seen in the Gulf of Naples where a few of the scarce specimens collected showed medusa buds (VANnUCCI, 1966). The wide geographical distribution of this species may be favoured by its ability to reproduce asexually. However, the presence of 
dense populations of individuals scarcely with buds suggests either that the area off Cananeia is a good breeding ground for the hydroid or that the species is differentiated into populations with different tendencies respectively towards asexual and sexual propagation, which in turn may be determined by environmental factors.

Laodicea minuscula was found more frequently in the samples taken at the station without any thermocline and with salinity higher than 36\% in the lower layer, indicating an inflow of Tropical Water in the area. This is interesting, because in earlier papers this species was considered to be an indicator of the coastal water mass (VANNUCCI, 1957, 1963). The present findings show that this is evidently a ubiquitous species. The vertical distribution of the species, observed mainly on September 22, 1960 during the $24 \mathrm{hr}$. period, suggests a vertical diurnal migration, because the specimens were found near the bottom in the daytime, but at the surface and in the midwater at midnight, none being found near the bottom.

Adult specimens belonging to the genus Obelia can not be reliably determined down to species level. On Novemberr 7, 1961, a drift wood overgrown by Obelia hydroids was found in the area and brought into an aquarium, then medusae of Obelia hyalina CLARKE 1879 were liberated from them. This identification was made by counting the number of gastrodermal cells in the tentacles and in the tentacle root, as well as by other characteristics (VANNUCCI, 1955). Obelia species are found mainly in the coastal waters, and this explains their relative scarcity in the present collection. Most specimens were taken along with the hydroids covering the logs, and medusae were liberated from the hydroids. This fact suggests that the specimens found in the present collection may belong to the species mentioned above. GougH (1905) recorded a definite diurnal migration in Obelia sp., noting that it was taken at the surface during the dark hours from 8 p.m. to 1 a.m. Russell (1925) noticed that the daytime distribution is altered little or not at all at night. FurNestin (1959) noticed that Obelia sp. was more abundant in day hauls than in night hauls in the Moroccan waters. VuCETIC (1961) found Obelia dichotoma in the 10-20 m layer only at night and in the $20-30 \mathrm{~m}$ or deeper layers at noon in the Bay Veliko Jezero of the Island of Mljet. Obvious upwards migration during the dark period was observed in the present study. The discordant notice given by RuSSELL (op. cit.) on the behaviour may probably be due to observations made on different species in different place.

The species of Phialidium found in the present collection could not be identified down to species level, because these delicate medusae were rather damaged. The number of specimens at respective stations was not large enough for study of diurnal vertical migration. However, the majority of specimens came from the midwater to the bottom in the daytime and the inverse was noticed at night. These figures seem to suggest strongly that these species undertook vertical migration.

Proboscidactyla ornata was a species which occurred at all stations. Some specimens carried medusa buds and stolons. The vertical migration of this species was noted previously by VANNUCCI (1957). As the thermocline acted as a barrier to the 
migrants it seems that this eurythermal species, in spite of its adaptive capacity, cannot withstand rapid changes in temperature.

About $72 \%$ of the total specimens of Liriope tetraphylla were taken in the water of temperatures lower than $19^{\circ} \mathrm{C}$. Earlier records (VANNUCCI, 1957) off southern Brazil have shown that Liriope tetraphylla prefers the water of salinity 35-36\% and of temperature $20-25^{\circ} \mathrm{C}$. In the Gulf of Naples, VANNUCCI (1966) recorded this species at salinity $37 \%$ and temperature from 14.2 to $15.6^{\circ} \mathrm{C}$, and mature medusae were included in her collection. The occurrence of a great number of specimens and of breeding populations at low temperatures suggests that this warm water species can survive at least for a certain period in the water of temperatures lower than its optimum. The diurnal vertical migration of this species has already been referred to by RusselL (1927) and Moore (1949). According to Furnestin (1959), this species is found more frequently and abundantly in night rather than day hauls, except during the summer and autumn seasons, then the situation is reversed. She correlated these variations with the seasonal variations in the percentage of juveniles in the population, and suggested some differences in the behaviour between juveniles and adults. The present data showed a very marked vertical migration of this species at night, but not to the surface when the coastal water was spread there.

The majority of specimens of Amphogona apsteini found in the present collection was young. In a total of 3,800 specimens, $3,752(98.74 \%)$ were young, while only 48 $(1.26 \%$ of the tota) were adults. This species was present at all stations, except on January 1962. VANNUCCI (1963) noted similarly the scarcity of adults off Cananeia and suggested that the young and immature specimens could tolerate a lower salinity or that adults had died soon after spawning. It is interesting to point out that a total of 2,813 specimens $(74 \%$ of the total) were found near the bottom. Only 6 specimens $(1.15 \%$ of the total) were found near the surface at two of the six stations where this species occurred and they were all adults and taken at night. The vertical migration of the adults itself could not be studied exactly, but the presence of only adults at the surface only at night suggests that the adults perform the diurnal vertical migration.

VANNUCCI (1963) refers to the close association between Aglaura hemistoma and the Tropical Waters. In the present investigation, the greatest catches of this species were made also in the Tropical Waters. The vertical migration of this species has been suggested already by FURNESTIN (1959).

All the specimens of Solmundella bitentaculata were found in the cold midwater or near the bottom, but never at the surface. VANHOFFEN (1908) stated that Solmundella is the most widely distributed narcomedusan, ranging from the North Atlantic through the tropical Pacific and Indian Ocean to the Antarctic, living at temperatures of $27^{\circ}$ to $-1{ }^{\circ} \mathrm{C}$ and in depths ranging from 1,500 fathoms to the surface. The fact that in the present samples here studied it did not occur at the surface may indicate its preference for lower temperatures, too. The vertical migration of this species was also suggested early by Furnestin (1959). MACKInTosh (1934) noticed 
an obvious vertical migration of Solmundella bitentaculata in the Antarctic waters.

The majority of the specimens of Solmaris spp. found in the present collection is rather damaged, but some well preserved specimens could be identified with Solmaris leucostyla (WILL, 1844). The species previously known from the southern Brazilian coast are: $S$. flavescens and S. leucostyla (VANnucci, 1957). More information is needed for the behavioural studies of these species. At present, the records of these species near the surface could not be related to the dark-hours and thus could not suggest the diurnal vertical migration.

Two species belonging to the genus Cunina in the Cananeia region (South of Brazil) were referred to by VANNUCCI (1963): C. octonaria and C. peregrina, the first being more than seven times as abundant as the last. In the present material, some specimens were rather damaged, but all the complete specimens were identified with C. octonaria. Larvae were found attached to adults and parasitic stolon larvae were found in specimens of Liriope tetraphylla. Neither the thermocline nor the halocline seems to interfere with the vertical movement of this species which presents one of the most conspicuous examples of daily vertical migration in planktonic animals. This has never been referred to before, although VANNUCCI (1957) noticed that the richest hauls were made at night.

\section{Summary}

1. This paper presents descriptions on the behaviour of some Hydromedusae relating to their diurnal vertical migration, by deduction from sampling data.

2. The plankton samples were taken at about quarterly intervals over a period of three years at a fixed point 24 miles off the Santos Harbour, southern Brazil.

3. A total of 129,652 medusae were studied, including 8 species of Anthomedusae, 2 species of Leptomedusae, 1 species of Limnomedusae, 3 species of Trachymedusae and 2 species of Narcomedusae, besides some species of Phialidium and Obelia (Leptomedusae) and Solmaris (Narcomedusae).

4. Merga tergestina is a new record to the South Atlantic Ocean.

5. Five species showed a marked diurnal vertical migration: Euphysora gracilis, Cytaeis tetrastyla, Proboscidactyla ornata, Liriope tetraphylla and Cunina octonaria.

6. The majority of specimens of Ectopleura dumortieri, Turritopsis nutricula and Obelia spp. migrated from the bottom to the midwater within the subtropical water mass.

7. The thermocline appears to act as a barrier to the migratory movement of Proboscidactyla ornata.

8. The thermocline was not effective as a barrier to the migratory movement of Liriope tetraphylla and Cunina octonaria.

9. Euphysora gracilis, Liriope tetraphylla and Cytaeis tetrastyla did not migrate up to the surface when the low salinity water was spread there.

10. Bougainvillia frondosa, Laodicea minuscula, Phialidium spp., Amphogona 
apsteini, Aglaura hemistoma and Solmundella bitentaculata either were found in insufficient numbers to allow any detailed analyses or did not show any clearly defined migration; though from the known data it is inferable that they probably migrate.

11. The data are not sufficient to describe the behaviours of Eucodonium brownie Bougainvillia ramosa, Merga tergestina, Eucheilota duodecimalis and Solmaris spp.

12. The known limits of temperature and salinity were given additionally for some species.

\section{Acknowledgements}

1 wish to express my indebtedness to the staff of the Oceanographic Institute (University of São Paulo), mainly to Mr. Benedito QuinTERo, skipper of the vessel "Emilia" at the time of the sampling and to her crew, who made possible the extensive collecting at sea. A very special aknowledgement is due to the late Mr. Hermenegildo SANTANA, who was one of the best helps and with his gaiety and good humour made the long days and nights of hard work less tiresome.

Thanks are due to Dr. Marta VANNucci, who headed this work and assisted in the medusae identification; to Dr. C. Burdon-Jones and Dr. Paulo SAWAYA, who read the manuscript critically; to Dr.T. BJörNBERG and Dr. P. S. MoreIRA for their helpful criticism and suggestions. To Dr. I. EMILSSON I am grateful for reading the hydrographical notes critically.

\section{REFERENCES}

Almeida Prado, M. S. A. 1960. A new species of Sagitta from the southern Brazilian Coast. Anais Acad. Bras. Cienc. 32 (2): 275-280.

, 1961. Distribuição dos Chaetognatha no Atlantico Sul Ocidental. Bolm. Inst. Oceanogr., S. Paulo, 11 (4): 15-49

1968. Distribution and annual occurrence of Chaetognatha off Cananéia and Santos coast (São Paulo, Brazil). Bolm. Inst. Oceanogr. S. Paulo, 17: 33-55.

BJörnBerG, T. K. S. 1963. On the marine free-living copepods off Brazil. Bolm. Inst. Oceanogr., S. Paulo, 13 (1): 3-142.

, 1965. The study of planktonic copepods in the South West Atlantic. Anais Acad. Bras. Cienc. 37 (Suplemento): 219-230.

BjörnberG, T. K. S. and Wilbur, K. M. 1968. Copepod phototaxis and vertical migration influenced by xanthene dyes. Biol. Bull. Woods Hole, 134 (3): 398-410.

Bogorov, B. G. 1946. Peculiarities of diurnal vertical migrations of zooplankton in polar seas. J. mar. Res., 6 (1): 25-32.

1958. Perspectives in the study of seasonal changes of plankton and of the number of generations at different latitudes, p.145-158. In Perspectives in Marine Biology. Ed. A. A. Buzzati-Traverso. Univ. Calif. Press. Berkeley.

Cuvier, G. 1882. Le regne animal, vol. 17, 278 p. Fortin, Masson et Cie, Paris.

Emilsson, I. 1956. Relatório e resultados fisico-quimicos de três cruzeiros oceanográficos em 1956. Contr. avul. Inst. Oceanogr. Ocean. Fisica, $\mathrm{n}^{\circ} 1,70 \mathrm{p}$.

_- 1959. Alguos aspectos fisicos e quimicos das aguas marinhas brasileiras. Cienc. Cult., S. Paulo, 11 (2): 44-54.

, 1961. The shelf and coastal waters off Southern Brazil. Bolm. Inst. Oceanogr., S. Paulo 11 (2): 101-112.

, 1963. Sôbre o ciclo anual da estrutura termohalina das águas em frente do litoral de São Paulo. Cienc. Cult., S. Paulo 15: 298-299. 
ForNERIs, L. 1965. Appendicularian species groups and Southern Brazil water masses. Bolm. Inst. Oceanogr., S. Paulo 14: 53-114.

Furnestin, M. L. 1959. Méduses du plancton Marocain. Révue Trab. Inst. (scient. tech.) Pêches marti. 23 (1): 105-124.

Gough, L. H. 1905. On the distribution and the migrations of Muggiaea atlantica CunNingham, in the English Channel, the Irish Sea, and off the South and West Coasts of Ireland in 1904. Cons. perm. int. Explor. Mer. Publ. Cir. 29: 493-519.

HIDA, T. S. and KING, J. E. 1955. Vertical distribution of zooplankton in the Central Equatorial Pacific, July-August 1952. Spec. Scient. Rep. U.S. Fish Wildl. Serv., 144: 1-22

HURE, J. 1961. Migration journalière et distribution saisonière verticale du zooplancton dans la région profonde de 1' Adriatique. Acta Adriatica 9: 1-59.

KING, J. E. and HIDA, T. S. 1954. Variations in zooplankton abundance in Hawaiian waters 1950-52. Spec. Scient. Rep. U. S. Fish Wildl. Serv. 118: 1-66.

$\&-$ 1957. Zooplankton abundance in the central Pacific. II. Fishery Bull. 118, Fish and Wildl. Serv., U.S. 57: 365-395.

KramP, P.L. 1930, Hydromedusae collected in the south western part of the North Sea and in the eastern part of the Channel in 1903-1914. Mém. Mus. r. Histo. nat. Bel. 45: 1-55.

$\longrightarrow$, 1933. Occasional notes on coelenterate. II. Vidensk. Meddr dansk naturh. Foren. 94: 237-247.

KuHL, H. 1962. Die Hydromedusen der Elbemundung. Abh. Verh. natur. Ver. Hamburg. N. F. 6: 209-232.

LEGAND, M. 1958. Étude sommaire des variations quantitatives diurnes du zoo-plancton autour de la Nouvelle Caledonie. Rapp. Scient. Inst. fr. Océanie 6: 1-42

Mackintosh N. A, 1934. Distribution of the macroplankton in the Atlantic sector of the Antarctic. 'Discovery' Rep. 9: 65-160.

Mascarenhas, A. S., Jr., Miranda, L. B. and Rock, N. J. 1971. A study of the oceanographic conditions in the region of Cabo Frio, p. 285-295. In Fertility of the Sea, vol. 1, Ed. John D. Costlow, Jr. Gordon and Breach Science Publishers, New York.

MCAllister, C. D. 1961. Zooplankton studies at ocean weather station 'P' in the northern Pacific Ocean. J. Fish. Res. Bd. Can., 18 (1): 1-29.

Mesoutta, A. R. 1969. Variações sazonais nas águas costeiras do Brasil-Lat. $24^{\circ} 30^{\prime}$. M. Sc. thesis. Oceanographic Institute U.S.P. 40 p. (unpublished)

Moore, H. B. 1949. The zooplankton of the upper waters of the Bermuda area of the North Atlantic. Bull. Bingham Oceanogr. Coll., 12 (2): 1-97.

MoreirA, G. S. 1965. Nota prévia sôbre a migração vertical diária de medusas. Anais Ac. Bras. Cienc., 37 (Suplemento): 246-255.

MoreirA, G. S. and YAmASHITA, C. 1972. Aglauropsis kawari (Limnomedusae, Olindiasidae), a new species from the South Atlantic Ocean. Marine Biology 14 (3): 271-274.

Moreira da Silva 1957. Oceanografia do Triângulo Cabo Frio, Trindade e Salvador. Anais Hidrográficos, 16: 213-308.

Moreira da Silva, P. C. and Rodrigues, R. F. 1966. Modificações na estrutura vertical das águas sôbre a borda da plataforma continental por infuência do vento. Inst. Pesq. Mar. Nota Técnica $\mathrm{n}^{\circ}-35 / 1966$.

NEPPI, V. 1912. Adriatische Hydromedusen. Sber. Akad. Wiss.-Wien, math-nat. 121 (1): 709-734.

NePPI, V. and Stiasny, G. 1911. Die Hydromedusen des Golfes von Triest. Zool. Anz. 39: 556-557

OKuDA, T. 1962. Physical and chemical oceanography over continental shelf between Cabo Frio and Vitoria (Central Brazil), J. oceanogr. Soc. Japan. 20th. Anniversary Volume: 515-540.

RUSSELL, F. S. 1925. The vertical distribution of marine macroplankton. An observation on diurnal changes. J. mar. biol. Ass. U.K. 13: 769-809.

—, 1927. The vertical distribution of plankton in the sea. Biol. Rev., 2 (3): 213-262.

- 1928. The vertical distribution of marine macroplankton. VI. Further observations on 
diurnal changes. J. mar. biol. Ass. U. K. 15: 81-103.

, 1938. The Plymouth offshore medusa fauna. J. mar. biol. Ass., U. K., 22: 411-439.

1953. The medusae of the British Isles. Cambridge Univ. Press. 530 p.

VANhÖFfEN, E. 1908. Die Narcomedusen. Wiss. Ergebn dt. Tiefsee-Exped. 'Valdivia' 19: 41-47.

VANNUCCI, M. 1955. On the newly liberated medusa of Obelia hyalina Clarke 1879. Dusenia 6 (1/2): $55-60$.

, 1957. On Brazilian Hydromedusae and their distribution in relation to different water masses. Bolm. Inst. Oceanogr., S. Paulo, 8 (1/2): 23-109

$\longrightarrow, 1963$. On the ecology of Brazilian medusae at $25^{\circ}$ lat. S. Bolm. Inst. Oceanogr., S. Paulo, 13 (1): 143-184.

_ - 1966. Total net plankton volume and Hydromedusae from fixed stations in the Gulf of Naples, p. 675-697. In Some Contemporary Studies in Marine Science, Ed. Harold Barnes. George Allen and Unwin Ltd., London.

Vannucci, M. and Moreira, G. S. 1966. New species and new record of Anthomedusae from Southern Brazil. Bolm. Inst. Oceanogr., S. Paulo, 15 (1): 85-89.

VannuCCI, M. and Yamada, M. 1959. The life cycle of Merga tergestina (Anthomedusae, Pandeidae). Pubbl. Stz. zool. Napoli, 31 (2): 320-333.

VERWEY, J. 1966. The role of some external factors in the vertical migration of marine animals. Netherlands Journal of Sea Research, 3 (2): 245-266.

Vinogradov, M. E. 1968. Vertical distribution of the oceanic zooplankton. Publishing House 'Nauka', Moscow. 320 p.

Vucetic, T. 1961. Vertical distribution of zooplankton in the Bay Veliko Jezero on the Island of Mljet. Acta Adriat. 6 (9): 3-20.

WALTER, J. 1893. Allgemeine Meereskunde. Leipzig. 296 p.

Welsh, J. H., Chace, F. A. and NunNemacher, R. F. 1937. The diurnal migration of deep-water animals. Biol. Bull. Woods Hole, 73 (2): 185-196.

WIBORG, K. F. 1955. Zooplankton in relation to hydrography in the Norwegian Sea. Rep. Norw. Fishery Marine Invest., 11 (4): 1-66. 


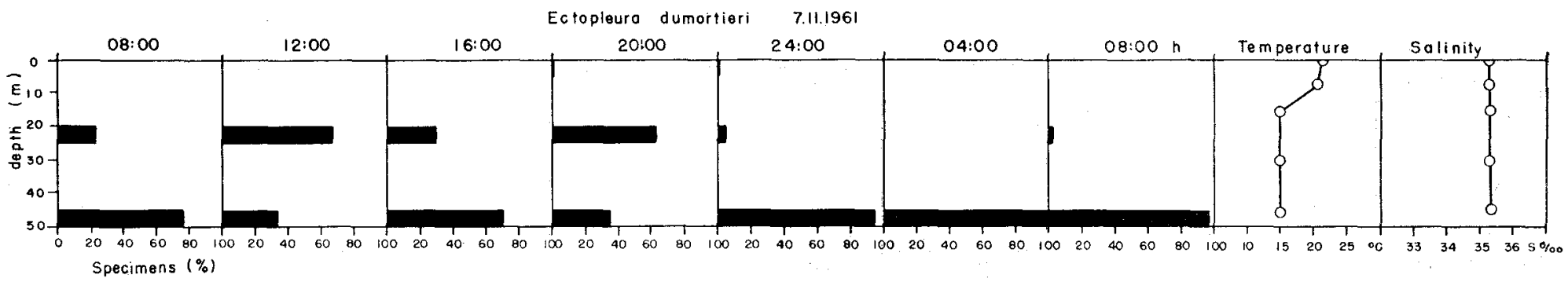

Fig. 1. Vertical distribution of Ectopleura dumortieri on November 7-8, 1961 .

Euphysora gracilis 21.3 .1961

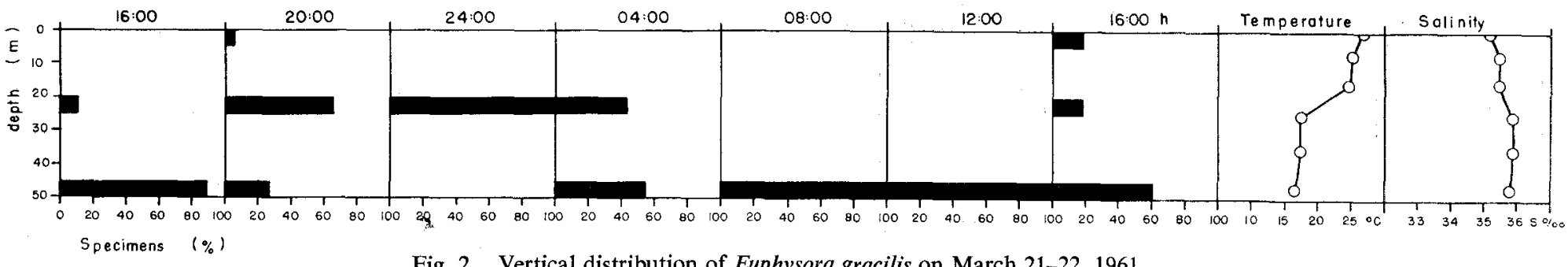

Fig. 2. Vertical distribution of Euphysora gracilis on March 21-22, 1961.

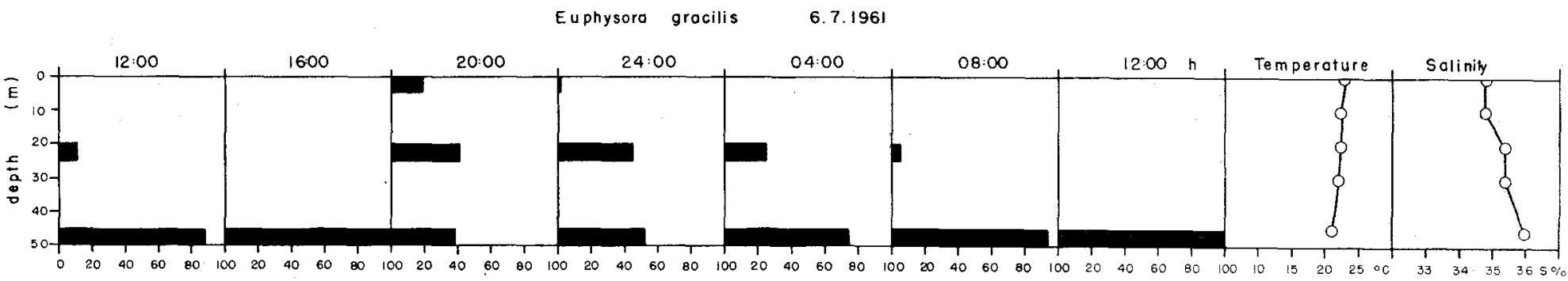

Specimes $(\%)$

Fig. 3. Vertical distribution of Euphysora gracilis on July 6-7, 1961. 


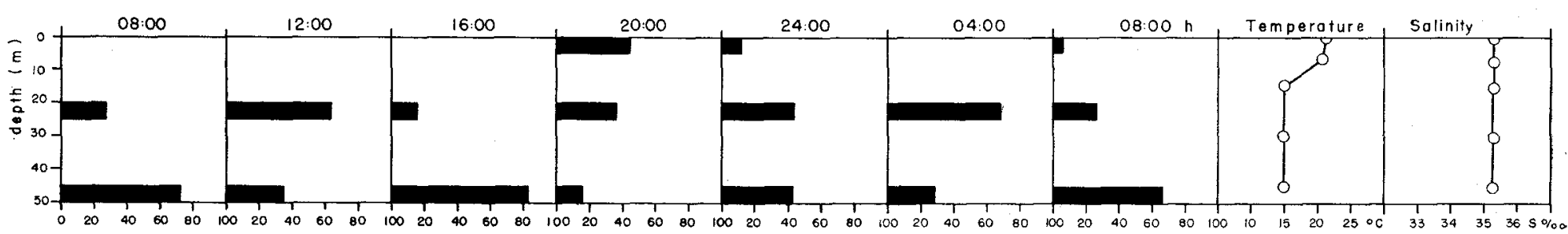

Specimes $(\%)$

Fig. 4. Vertical distribution of Euphysora gracilis on November 7-8, 1961.

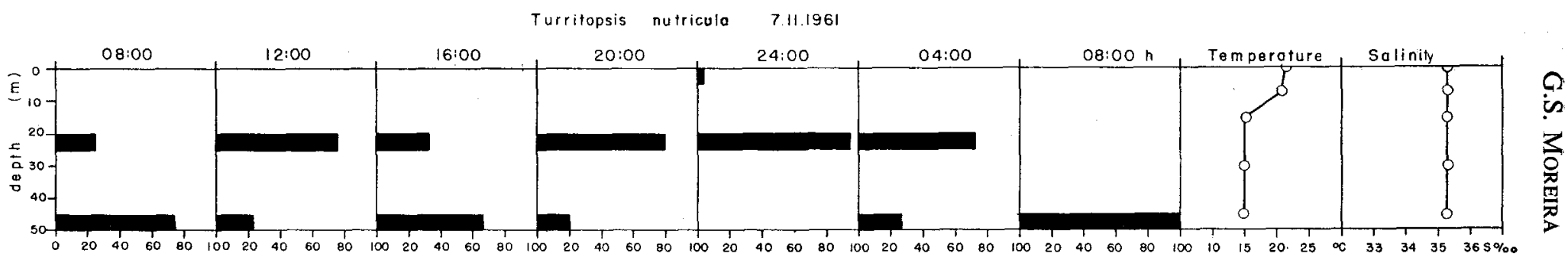

specimens $(\%)$

Fig. 5. Vertical distribution of Turritopsis nutricula on November 7-8, 1961.

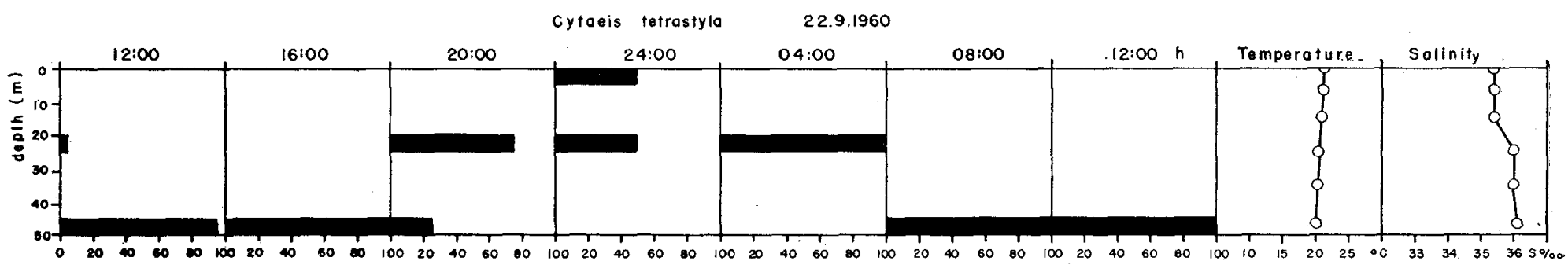
Specionens(8)

Fig. 6. Vertical distribution of Cytaeis tetrastyla on September 22-23, 1960. 


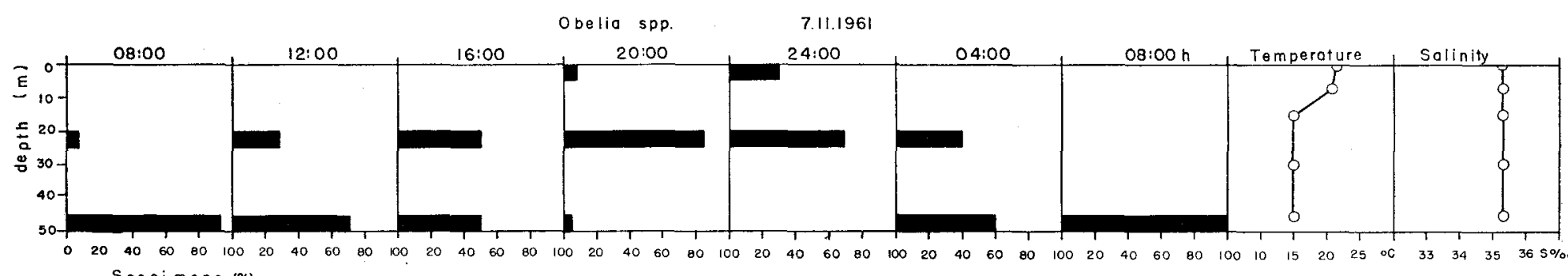

Fig. 7. Vertical distribution of Obelia spp. on November 7-8, 1961.

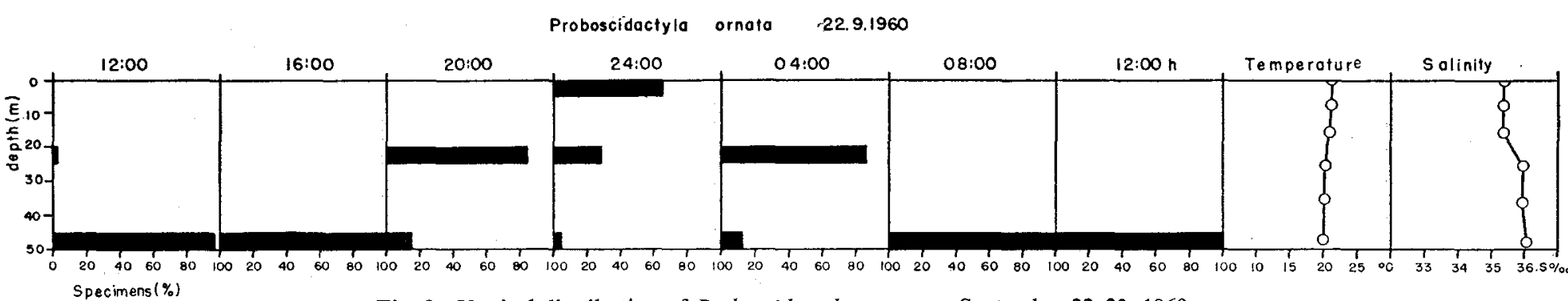

Fig. 8 Vertical distribution of Proboscidactyla ornata on September 22-23, 1960.

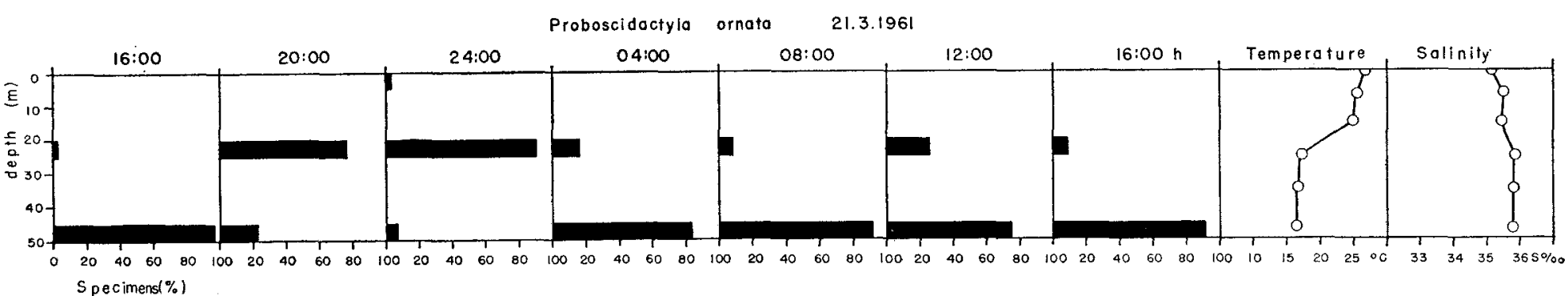

Fig. 9. Vertical distribution of Proboscidactyla ornata on March 21-22, 1961. 


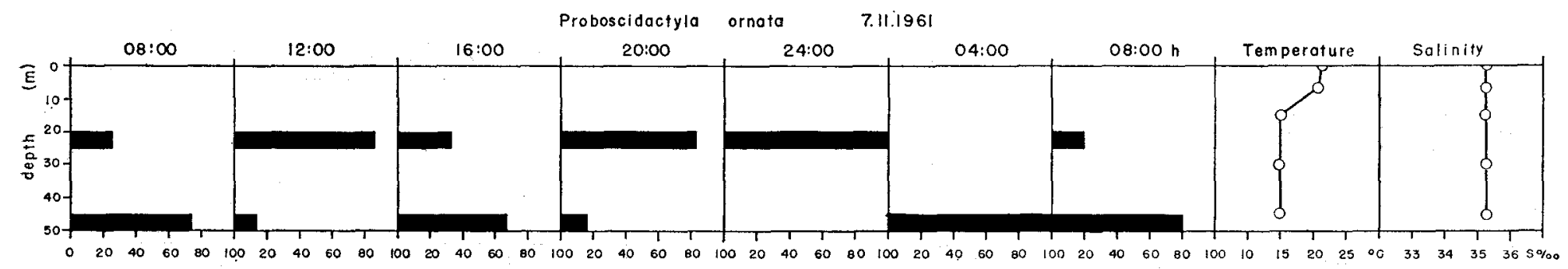

Fig. 10. Vertical distribution of Proboscidactyla ornata on November 7-8, 1961.

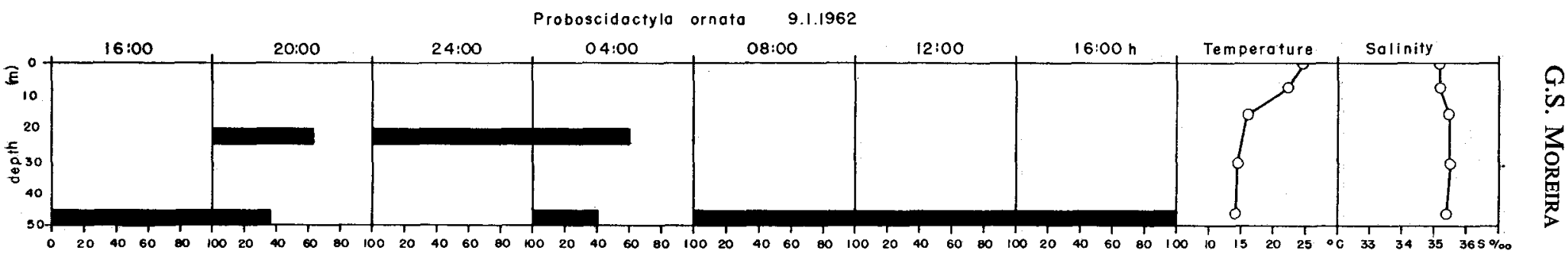

Specimens $\%$

Fig. 11. Vertica distribution of Proboscidactyla ornata on January 9-10, 1962.

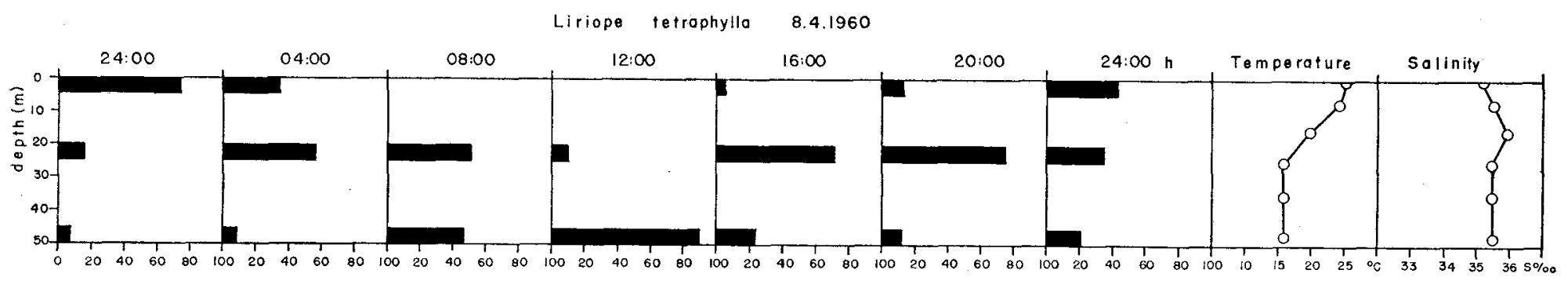

Specimens $(\%)$

Fig. 12. Vertical distribution of Liriope tetraphylla on April 8, 1960. 


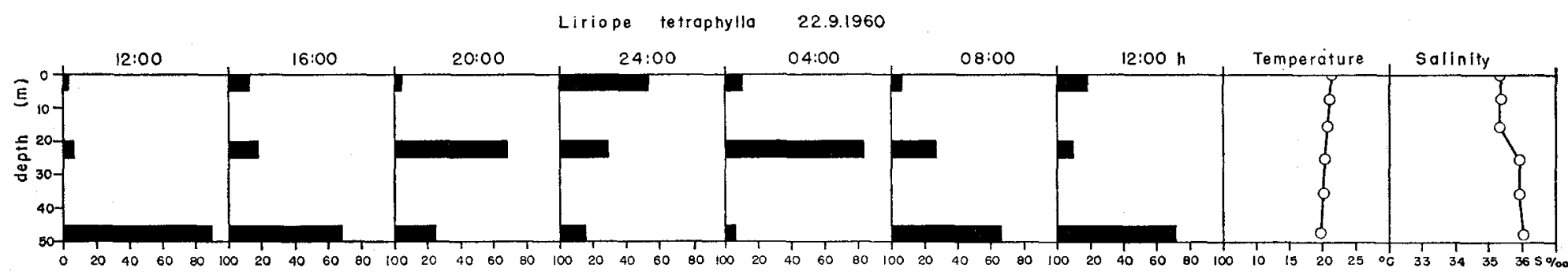

Specimens $(\%)$

Fig. 13. Vertical distribution of Liriope tetraphylla on September 22-23, 1960.

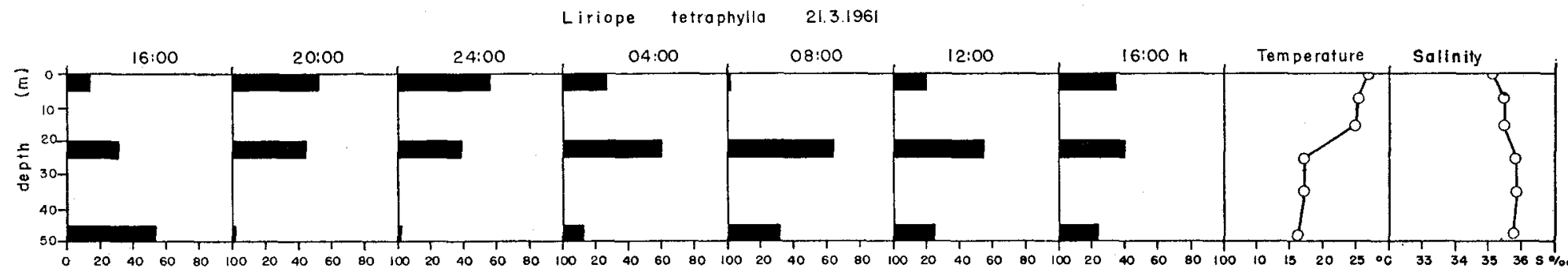

Fig. 14. Vertical distribution of Liriope tetraphylla on March 21-22, 1961.

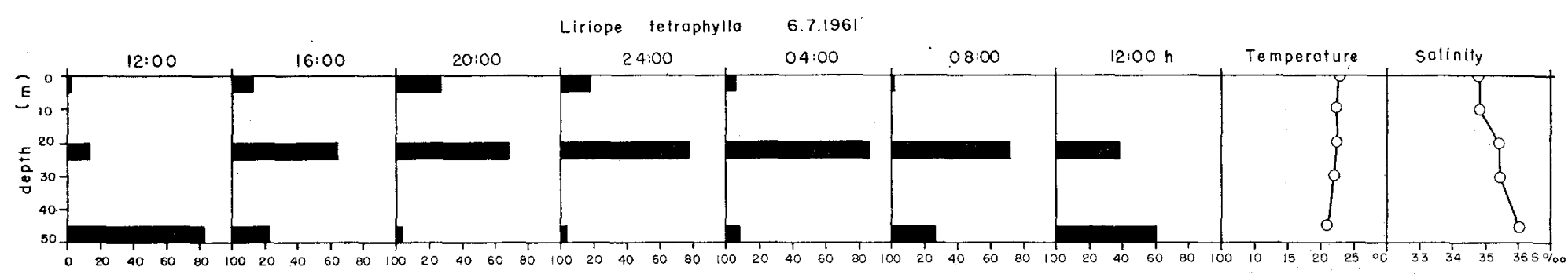
Specimens $(\%)$

Fig. 15. Vertical distribution of Liriope tetraphylla on July 6-7, 1961. 


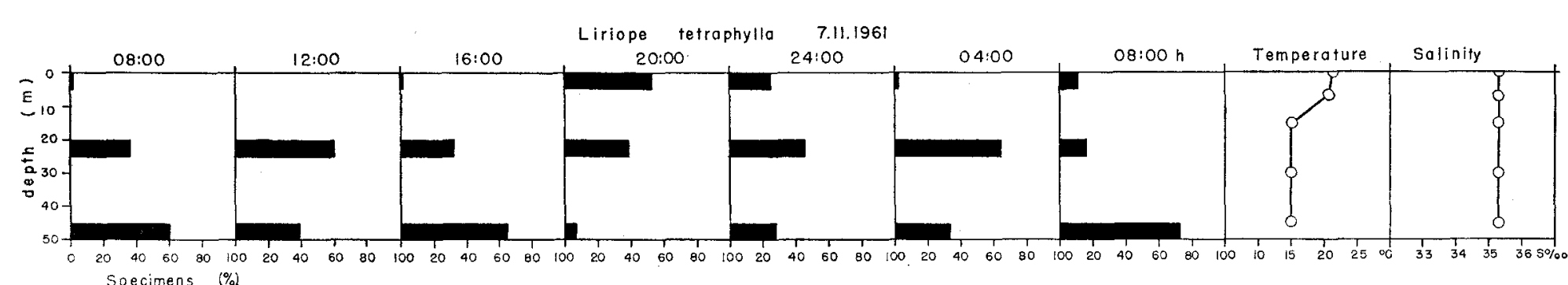

Fig. 16. Vertical distribution of Liriope tetraphylla on November 7-8, 1961.

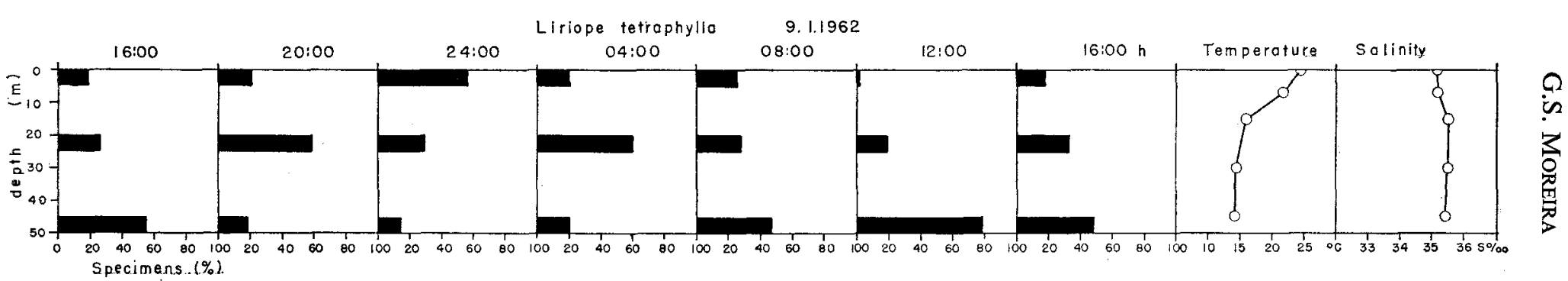

Fig. 17. Vertical distribution of Liriope tetraphylla on January 9-10, 1962.

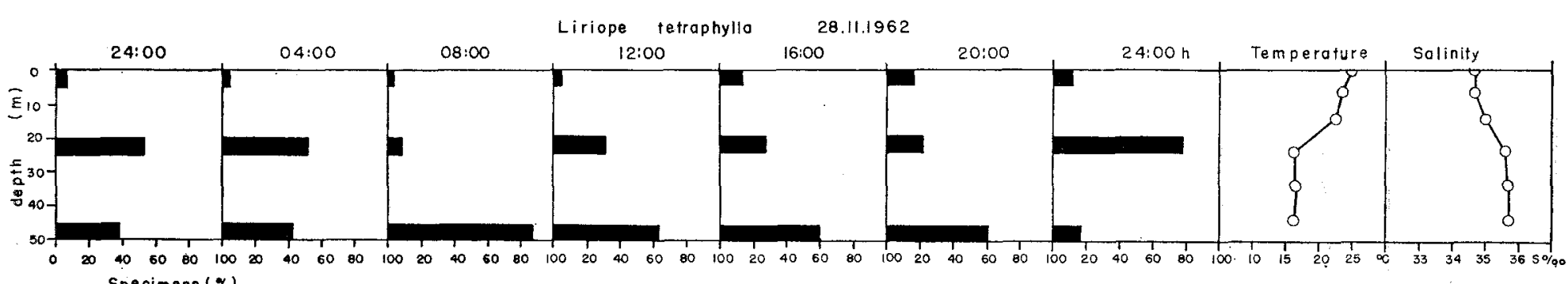

specimens $(\%)$

Fig. 18. Vertical distribution of Liriope tetraphylla on November 28, 1962. 


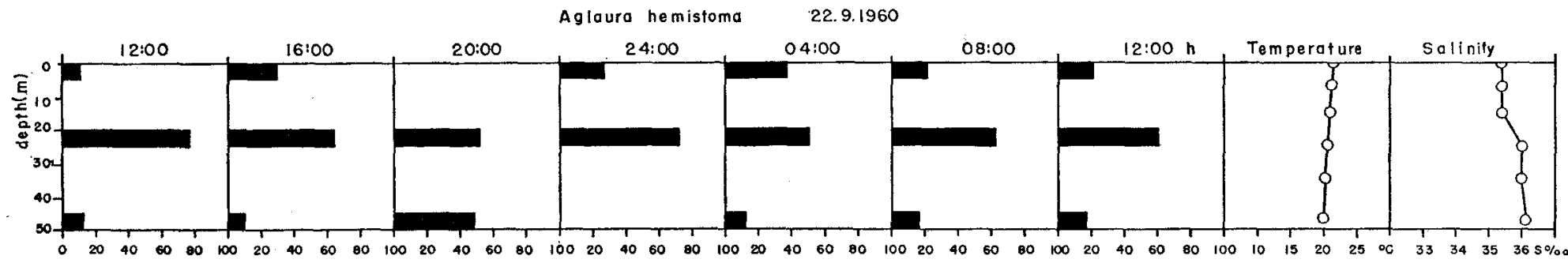

Specimens (\%)

Fig. 19. Vertical distribution of Aglaura hemistoma on September 22-23, 1960.

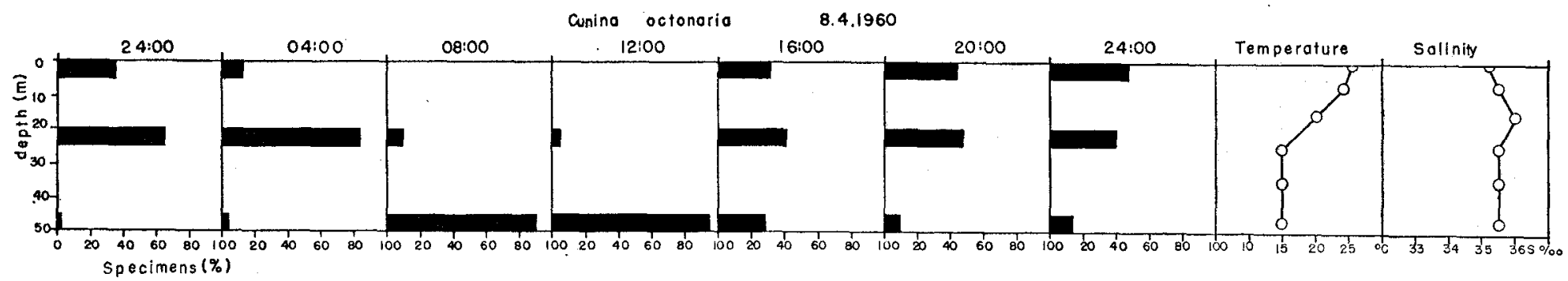

Fig. 20. Vertical distribution of Cunina octonaria on April 8, 1960.

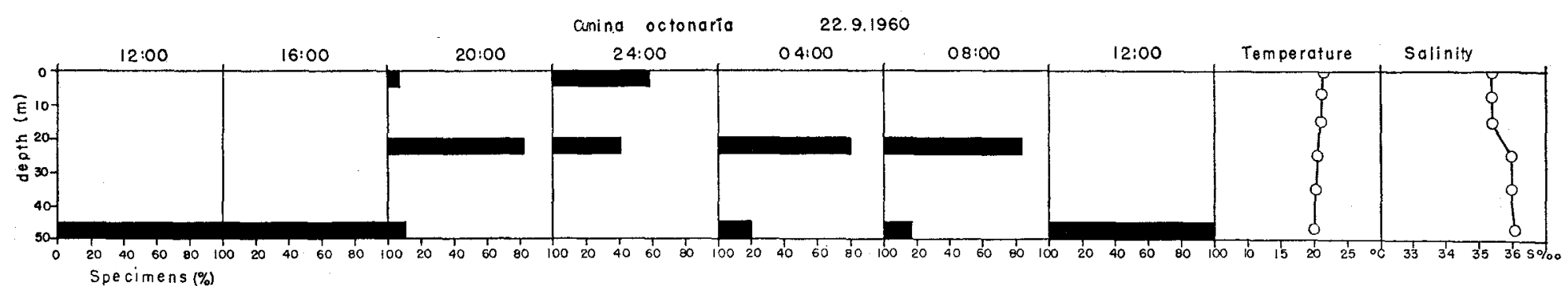

Fig. 21. Vertical distribution of Cunina octonaria on September 22-23, 1960. 


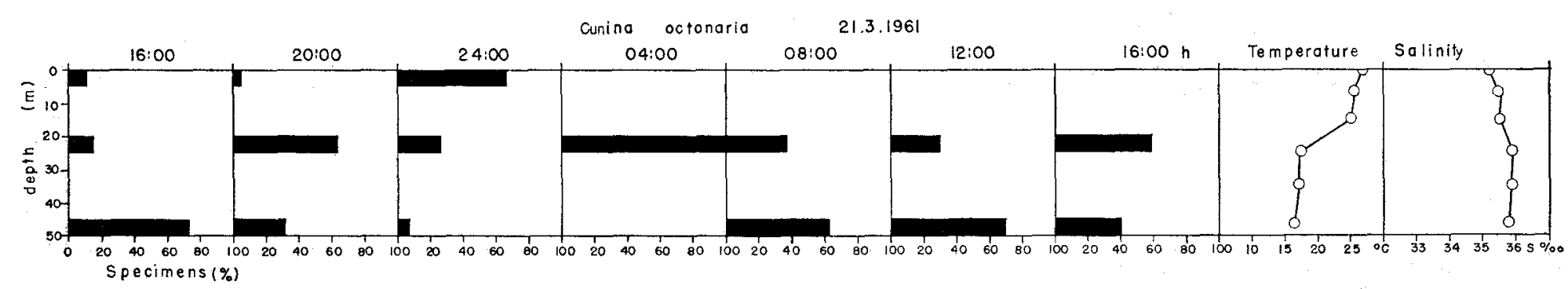

Fig. 22. Vertical distribution of Cunina octonaria on March 21-22, 1961.

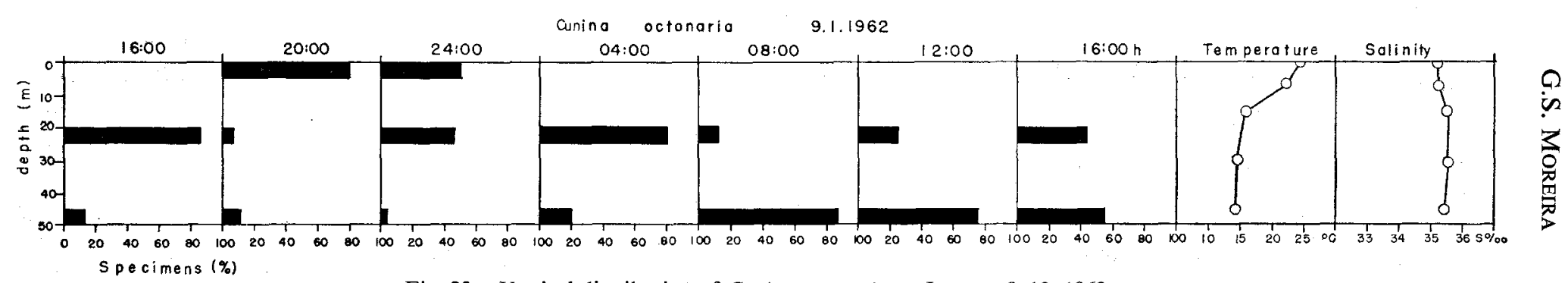

Fig. 23. Vertical distribution of Cunina octonaria on January 9-10, 1962. 